Schulich School of Law, Dalhousie University

Schulich Law Scholars

Articles, Book Chapters, \& Blogs

Faculty Scholarship

2016

Consent to Psychiatric Treatment: From Insight (into Illness) to Incite (a Riot)

Sheila Wildeman

Follow this and additional works at: https://digitalcommons.schulichlaw.dal.ca/scholarly_works

Part of the Health Law and Policy Commons, Law and Politics Commons, Law and Society Commons, and the Medical Jurisprudence Commons 


\section{Consent to psychiatric treatment: From insight (into illness) to incite (a riot) Sheila Wildeman*}

[pre-publication version of chapter included in Colleen Flood \& Jennifer Chandler, eds, Law and Mind: Mental Health Law and Policy in Canada (Toronto: LexisNexis, 2016).]

\section{Introduction}

Debates concerning treatment decision-making in the embattled domain of mental health law tend to centre upon the right to refuse treatment. ${ }^{1}$ In these debates, refusal is positioned as the last card to be played in a contest between the individual identified as in need of treatment (for whom the prospect of treatment constitutes a threat of profound, identity-annihilating violence) and the health provider charged with advancing the individual's and/or the public's welfare. ${ }^{2}$ Focusing on the right to refuse -- while scrutinizing the limits on that right - has the merit of drawing attention to the dynamics of power and resistance inherent in the diagnosis and treatment of mental health disability. Moreover, the right to refuse gives concrete expression to an essential dimension of the value of liberty - i.e., liberty as "negative freedom." 3 The importance of freedom from state-backed coercion - or, more precisely, the importance of the guarantee that such freedom will not be limited except in accordance with the procedural and substantive protections integral to public justification - cannot be overstated. Where the freedom in question engages the preservation of one's bodily integrity as well as one's mental states, then its importance must be recognized as of the highest order.

And yet negative freedom is but one expression of the normative construct of autonomy that gives shape to the law on treatment decision-making in and beyond mental health settings. That is, as this chapter explores, the law on consent to psychiatric treatment is concerned not only with voluntariness but also with what it means for treatment choice to be adequately informed - an element of consent placing positive legal duties on health providers. Moreover, debates on the law structuring psychiatric treatment choice have in recent years been increasingly oriented to the prospect of duties placed on both health professionals and more broadly on the state to provide supports and resources (beyond information) to assist individuals in exercising legal capacity and so in actualizing the right to medical self-determination.

\footnotetext{
* Thanks to Jennifer Chandler and Colleen Flood for bringing together this project and for their patient editorial assistance. Thanks also to Ilana Luther and Brad Abernethy, and the anonymous reviewers. ${ }^{1}$ A few diverse examples from the Canadian literature on the right to refuse psychiatric interventions (reaching back to the 1980s and 90s) include C.H. Cahn, "The ethics of involuntary treatment: the position of the Canadian Psychiatric Association" (1982) 27 Can J Psychiatry 67; Bonnie Burstow \& Don Weitz, Shrink Resistant: The Struggle Against Psychiatry in Canada (Vancouver: New Star, 1988); Isabel Grant, "Mental Health Law and the Courts" (1991) 29:4 Osgoode Hall Law Journal 747; Thomas G. Gratzer and Manuel Matas, "The Right to Refuse Treatment: Recent Canadian Developments" (1994) 22:2 Bulletin of the Am Academy of Psychiatry and Law 249; Sarah MacKenzie, "Informed Consent: The Right of Psychiatric Patients to Refuse Treatment" (1993) DJLS 59.

${ }^{2}$ See Sophie Nunnelly's argument in Chapter xx that strategies of public justification for forced treatment tend to shuttle unstably between conceptions of public safety and individual welfare.

${ }^{3}$ Isaiah Berlin, "Two Concepts of Liberty" in Isaiah Berlin, Four Essays on Liberty (Oxford: Oxford University Press, 1969) 118.
} 
The aim of this chapter is to go back to the basics on consent to treatment, starting with the right to refuse and building from there. Part II addresses the leading judicial statements on the value of medical self-determination, and in light of these statements, considers what is at stake in psychiatric treatment choice. Part III explores the three core elements of valid consent to treatment -- namely that consent be voluntary, informed and capable -- with attention to variation in the law amongst provinces and territories, and some lines of analysis and critique specifically applicable to mental health care contexts. Part IV considers new directions in law and policy clustering around the concept of supported decision-making - a concept forged through domestic and international disability rights advocacy, which urges fundamental re-examination of the interrelationship of legal capacity, autonomy and distributive justice. ${ }^{4}$

\section{Fundamental legal values - and what is at stake in consent to psychiatric treatment}

The Supreme Court of Canada has placed a high priority on the right to "decide one's own fate" 5 in respect to medical decisions. The leading statements on point were recently consolidated in the unanimous judgment in Carter v. Canada:

The law has long protected patient autonomy in medical decisionmaking...competent individuals are - and should be - free to make decisions about their bodily integrity" [. . .]. This right to "decide one's own fate" [...] underlies the concept of "informed consent" and is protected by s. 7's guarantee of liberty and security of the person [...]. [T] he right of medical selfdetermination is not vitiated by the fact that serious risks or consequences, including death, may flow from the patient's decision. ${ }^{6}$

The value of medical self-determination applies with comparable intensity in disputes about psychiatric treatment. In Starson $v$ Swayze, ${ }^{7}$ a judgment addressing a disputed assessment of decision-making capacity under Ontario law (discussed later in this chapter), the majority observed:

\footnotetext{
${ }^{4}$ For a critique of the failure to shift from a paternalistic and coercive model of mental health law and policy in Canada to a model oriented instead to addressing the social determinants of mental health, see $\mathrm{H}$. A. Kaiser, "Canadian Mental Health Law: The Slow Process of Redirecting the Ship of State” (2009) 17 Health Law Journal 139.

${ }^{5}$ Carter v. Canada (Attorney General), 2015 SCC 5, [2015] 1 SCR 331 at para 67, citing A.C. v. Manitoba (Director of Child and Family Services), 2009 SCC 30, [2009] 2 SCR 181 at para 39. See also the valuable analysis of the background case law in Simon N Verdun-Jones \& Michelle S Lawrence, "The Charter Right to Refuse Treatment: A Comparative Analysis of the Laws of Ontario and British Columbia Concerning the Right of Mental-Health Patients to Refuse Psychiatric Treatment" 46:2 UBC Law Review 489 at 490-498.

${ }^{6}$ Carter v Canada (Attorney General), 2015 SCC 5, [2015] 1 SCR 331 at para 67 [citations omitted].

72003 SCC 32, [2003] 1 SCR 722.
} 
The right to refuse unwanted medical treatment is fundamental to a person's dignity and autonomy. This right is equally important in the context of treatment for mental illness. ${ }^{8}$

In Starson, the Court further observed (now citing the Ontario Court of Appeal in Fleming v. Reid ${ }^{9}$ ):

Few medical procedures can be more intrusive than the forcible injection of powerful mind-altering drugs which are often accompanied by severe and sometimes irreversible adverse side effects. ${ }^{10}$

This statement has been criticized on the argument that it overplays the dangers of psychiatric medications and minimizes their positive effects. ${ }^{11}$ In this vein, the human needs orientation to the law on consent to psychiatric treatment argues for attention to the ways that psychiatric medications may not only restore health but also liberty (i.e., freedom from involuntary confinement), and autonomy (i.e., the rationality that informs self-direction). ${ }^{12}$ The critics argue more specifically that the courts failed to appreciate what was at stake in both Fleming v. Reid and in Starson - both cases involving psychiatric treatment refusal in the context of involuntary psychiatric hospitalization. In such cases, the critics argue, the putative interest in treatment refusal should be more explicitly or carefully weighed against the possibility of indefinite detention and its effects not only on the individual him or herself, but also other patients and staff. ${ }^{13}$

One response to the critics is simply to return to the overwhelming priority placed on medical self-determination in the leading cases. This suggests, if not a clear normative preferencing of the interest in bodily and psychological integrity over the interest in freedom from restricted mobility, then in any case a determination that individuals should

${ }^{8}$ Ibid at para 75.

${ }^{9}$ (1991), 4 OR (3d) 74 (CA).

${ }^{10}$ Ibid at $\mathrm{p} 88$, cited in Starson v. Swayze, supra note $\mathrm{x}$ at para 75.

Robins JA lists a range of side effects of antipsychotic drugs, including: muscular side effects known as extra- pyramidal reactions: dystonia (muscle spasms, particularly in the face and arms, irregular flexing, writhing or grimacing and protrusion of the tongue); akathesia (internal restlessness or agitation, an inability to sit still); akinesia (physical immobility and lack of spontaneity); and Parkinsonisms (mask- like facial expression, drooling, muscle stiffness, tremors, shuffling gait). The drugs can also cause a number of non- muscular side effects, such as blurred vision, dry mouth and throat, weight gain, dizziness, fainting, depression, low blood pressure and, less frequently, cardiovascular changes and, on occasion, sudden death. (ibid)

${ }^{11}$ See John E. Gray, Margaret A. Shone \& Peter F. Liddle, Canadian Mental Health Law and Policy, $2^{\text {nd }}$ ed (Markham: LexisNexis, 2008) at 11-14 (distinguishing a "human needs" perspective on mental health law and policy -- based in a biological model of the roots of mental health disability, and more specifically, the thesis that "lack of insight" into illness or the need for treatment has a biological cause) from a "civil libertarian" perspective (one "that views mental health legislation as an often-unjustifiable intrusion by the state on the freedom of the individual"); and at 45 (objecting to the terms "mind controlling" and "mind altering" used by Robins JA in Fleming $v$ Reid).

${ }^{12}$ Ibid at 235-242.

${ }^{13}$ Ibid at 242-247. 
be given their "choice of hells," 14 i.e. the right to weigh on their own terms the relative awfulness of the prospects (as these are constructed in the dominant institutional framework) of indefinite detention without treatment or possible release conditional on treatment. Another response turns upon the point that there continue to be serious controversies about the safety and efficacy of psychiatric medications. ${ }^{15}$ Related to this is the observation that it cannot be predicted with certainty what effect (within a broad range of possible effects) a given drug will have in the individual case - whether in terms of side effects or primary intended effect. ${ }^{16}$ In other words, one cannot simply assume that individuals such as Starson or Reid will or would ever respond to medications in a manner deemed medically optimal.

Finally, discussion of what is at stake in psychiatric treatment choice must take account of the complexity of how treatment and non-treatment feel to the individual "from the inside." For instance, psychiatric medications and the conditions for which they are prescribed may interact with personal identity in complex ways, not easily translated to a typical risk-benefit profile. Thus while some who are diagnosed with mental health conditions may have no difficulty distinguishing themselves from mental states they would readily characterize as expressive of a disease, others understand their experiences in ambivalent or even positive terms - as part (even if a troubled part) of one's identity or of making meaning of one's life. ${ }^{17}$ Added to this is the further complexity that treatment refusal may be one piece of a broader politically and personally coherent objective of expressing resistance to what for many are highly adversarial encounters with the mental health system (i.e. police apprehension, restraints, forced injection). All this counsels an attitude of deference to, or respect for, the will and preferences of those who refuse psychiatric treatment.

\section{Consent in Law: Voluntary, Informed, and Capable}

The common law, along with Quebec's Civil Code, ${ }^{18}$ expresses the value of medical selfdetermination by requiring that consent be voluntary, informed, and capable. Several provinces have codified these three requirements. ${ }^{19}$

\footnotetext{
${ }^{14}$ Carla McKague in I. Shimrat, Call Me Crazy: Stories from the Mad Movement (Vancouver: Press Gang, 1997) at 71. McKague was co-counsel for the applicants in Fleming $v$ Reid.

15 See, e.g., James Davies, Cracked: Why Psychiatry is Doing More Harm Than Good (London: Icon Books, 2003).

${ }^{16}$ See, e.g., J. A. Lieberman et al., "Time Course and Biologic Correlates of Treatment Response in First Episode Schizophrenia," (1993) 50 Archives of General Psychiatry 369; J. A. Lieberman et al., "Effectiveness of Antipsychotic Drugs in Patients with Chronic Schizophrenia," (2005) 353 New England Journal of Medicine 1209.

${ }_{17}^{17}$ See Peter Bartlett \& Ralph Sandland, "Conceptualizing Mental Health Law" in Mental Health Law: Policy and Practice, $3^{\text {rd }}$ ed (Oxford: Oxford University Press, 2007) 1 at 2-10 ("Who are the insane?)

${ }^{18}$ Civil Code of Québec, CQLR c C-1991. For elaboration of the distinct approach to liability for unconsented-to touching and lack of informed consent in Quebec's civil law tradition, see Paul B. Miller, Sujit Choudry, and Angela Campbell, "Legal Regulation of the Physician-Patient Relationship" (particularly the section entitled "Civil Responsibility in Quebec Civil Law")

"http://www.royalcollege.ca/portal/page/portal/rc/resources/bioethics/primers/legal_regulation_of_the_phy sician_patient_relationship
} 
As discussed in more detail by Sophie Nunnelley in chapter X, the approach to treatment decision-making for people admitted involuntarily to psychiatric hospital tends to depart from these background legal requirements, although the precise terms of departure vary across Canadian provinces and territories. British Columbia effectively removes the requirement for an involuntary patient's consent on the fiction of "deemed" consent. ${ }^{20}$ In contrast, in Ontario, the law on consent to treatment is the same in cases of involuntary psychiatric hospitalization as in all other civil contexts. ${ }^{21}$ Thus involuntary patients have the right to refuse treatment as well as to have their prior capable refusals respected. In still other provinces and territories, capable as well as prior capable refusals of treatment may be overridden according to processes and standards specific to involuntary psychiatric patients. ${ }^{22}$ Finally, in a few provinces (Saskatchewan, Nova Scotia, and Newfoundland and Labrador), where involuntary psychiatric hospitalization is contingent upon incapacity to make decisions about treatment in or admission to psychiatric hospital, capable refusals are not contemplated among those with involuntary status. ${ }^{23} \mathrm{I}$ set aside the question of the constitutionality of these different limits on the right to refuse treatment, to be explored in Sophie Nunnelly's chapter. In what follows, I deal with the law on consent to treatment beyond the special case of involuntary psychiatric hospitalization. However, it is important to note that even where statute law authorizes involuntary treatment or other physical force to be applied to persons who are involuntarily in psychiatric hospital, there are still necessarily legal limits on such interventions. I make note of some of these limits in what follows.

\section{Voluntary consent}

Treatment or other bodily interference that is not consented to may give rise to liability in battery at common law, or charges under the Criminal Code (for instance, assault $(\mathrm{s} .265(1))) .{ }^{24}$ Alternatively, where the violation takes place in the exercise of a statutory

\footnotetext{
${ }^{19}$ Other provinces, as detailed below, have laws that speak to incapacity and substitute decision-making in health or mental health contexts, but just these four additionally set out the generally applicable prerequisites for valid consent to treatment. See BC's Health Care (Consent) and Care Facility (Admission) Act, RSBC 1996, c 181 [BC HCCFA]; Ontario's Health Care Consent Act, 1996, SO 1996, c 2, Sched A [Ontario HCCA], and Substitute Decisions Act, 1992, SO 1992, c 30; PEI's Consent to Treatment and Health Care Directives Act, RSPEI 1988, c C-17.2; and the Yukon's Decision-Making Support and Protection to Adults Act, SY 2003 c 21. See also the Civil Code of Québec, S.Q. 1991, c. 64, arts. 11 to 25. And see Patricia Peppin, "Informed Consent" in J. Downie, T. Caulfield \& C. Flood, eds., Canadian Health Law and Policy, 3rd ed. (Markham, Ont.: Butterworths, 2007) at 188. See also Cuthbertson v. Rasouli, [2013] 3 SCR 341, 2013 SCC 53 at paras 22-23, 52-53 (commenting on the relationship between Ontario's HCCA and the common law on consent to treatment).

${ }^{20}$ BC Mental Health Act, RSBC 1996, c 288, s.31.

${ }^{21}$ Ontario HCCA, supra note x; Ontario Mental Health Act, RSO 1990, c M.7 [Ontario MHA].

${ }^{22}$ See, e.g., Alberta's Mental Health Act, RSA 2000, c M-13, [Alberta MHA] s.29. For further examples and discussion, see Chapter X [Sophie Nunnelly's chapter].

${ }_{23}$ Saskatchewan Mental Health Services Act SS 1986-85-86, c M-13.1 [Sask MHSA], s.24(2); Nova Scotia Involuntary Psychiatric Treatment Act, SNS 2005 [NS IPTA], c 42, ss.17\&18; Newfoundland Mental Health Care and Treatment Act, SNL 2006, c M-9.1 [NL MHCTA], s.17.

${ }^{24}$ Criminal Code, RSC 1985, c C-46. One might also consider forcible confinement (s.279(2)), or the use of force not "required or authorized by law" (s.25(1)). I thank my colleague Archie Kaiser for assistance
} 
discretion, it may give rise to damages for a breach of the s.7 Charter right to liberty and security of the person. ${ }^{25}$

The plaintiff in a battery action in tort need only establish a non-trivial touching or interference with her person; ${ }^{26}$ proof of (further) injury is unnecessary. ${ }^{27}$ The most straightforward cases are those where there was not even an attempt to obtain consent to the intervention or treatment in issue. However, a battery may also occur where consent is putatively given but vitiated by fraud, duress, undue influence, or incapacity. ${ }^{28}$ The last of these legal concepts is dealt with further on in the chapter.

Fraud may vitiate consent, for example, where one medication is represented as another, or medication is delivered in a covert fashion (e.g., surreptitiously mixed into orange juice). ${ }^{29}$ A further example would be the administration of medication that was "not capable of constituting a therapeutic response to the patient's condition," yet was presented to the individual "as necessary." ${ }^{30}$ For example, consider the case of an antipsychotic medication administered for the purpose of control or administrative convenience, but presented (falsely) as "necessary" to assist with sleep or agitation. ${ }^{31}$ In such a case, it is arguable that this is a battery, as "the defendant's purpose is outside the plaintiff's permission". ${ }^{32}$

Consent may also be vitiated by duress, which describes the use or threat of force. ${ }^{33}$ Consider a situation in which a person is confronted by staff at the ready to restrain, and in that condition, is asked for "consent" to injectable treatment. This would seem an obvious case for arguing the vitiation of consent. That said, determining what constitutes

with identification of these Criminal Code offences. See also Archie Kaiser, "Mental Disability Law" Chapter 8 in Canadian Health Law and Policy, 2 $2^{\text {nd }}$ ed (Markham: Butterworths, 2002) 251 at 297.

${ }^{25}$ See Vancouver (City) $v$. Ward, 2010 SCC 27, [2010] 2 S.C.R. 28. And see also Hneihen v. Centre for Addiction and Mental Health 2014 ONSC 55 (CanLII) at paras 98-114.

${ }^{26}$ Non-Marine Underwriters, Lloyd's of London v. Scalera, [2000] 1 S.C.R. 551 at paras 8 \& 16.

${ }^{27}$ Reibl v. Hughes, 1980 CanLii 23 (SCC), [1980] 2 SCR 880 at p 890.

${ }^{28}$ See Allen Linden \& Bruce Feldthusen, Canadian Tort Law, $9^{\text {th }}$ ed. (Markham, ON: LexisNexis, 2011) [Linden \& Feldthusen] at 80-82.

${ }^{29}$ See Anten v. Bhalerao 2013 ONCA 499 (CanLII) at para 9: “The respondent's evidence about the medication regime and the effect of that medication on the appellant was confusing. It appeared that the first medication, including the anti-psychotic Risperidone, was at some point given to the appellant in her orange juice, "to improve her compliance." It was unclear when this medication regime began, when the hospital began to give it to her in her orange juice and whether the appellant knew it was in her orange juice. Then, on December 21, the appellant was given Risperidone in an injectable form. However, the appellant objected because of side effects." (italics added)

${ }^{30}$ See Dean v. Phung [2012] NSWCA and White v Johnston [2015] NSWCA 18 at paras 62-74, esp paras $69 \& 73$.

${ }^{31}$ See David Bruser et al, "Use of Antipsychotics Soaring at Ontario Nursing Homes" (Apr 15, 2014) The Star

(http://www.thestar.com/news/canada/2014/04/15/use_of_antipsychotics_soaring_at_ontario_nursing_hom es.html)

${ }^{32}$ White $v$ Johnston, supra note $\mathrm{x}$ at para 69.

${ }^{33}$ Linden \& Feldthusen, supra note $\mathrm{x}$ at 81 . The authors add: "nor is consent extracted from someone who is under the influence of drugs," citing Beausoleil v. La Communaute de Soeurs de la Charite (1964), 53 DLR (2d) 65 (Que QB). I put aside the question of whether drug-related impairment short of legal incapacity (eg, even mild sedation) might vitiate consent for the purposes of battery in health care contexts. 
a vitiating threat of force may be tricky in psychiatric treatment settings, where, even for voluntary patients, consent may be said to occur in the shadow of lawful coercion. For instance, some mental health laws provide that a voluntary patient may be forcibly detained for psychiatric assessment if he or she attempts to leave (and other diagnosis and risk-based conditions are met). ${ }^{34}$

In other contexts, the courts have not been receptive to the idea that consent may be vitiated by the strategic application of incentives and threats in institutional settings where there is lawful authority for the deprivation (or anticipated deprivation) of liberty. ${ }^{35}$ For example, in $R$. v Deacon, ${ }^{36}$ the Federal Court of Appeal held that it was within the jurisdiction of the National Parole Board ${ }^{37}$ and not a breach of $\mathrm{s.} 7$ of the Charter, to make compliance with medication (in this case, anti-anxiety medication and medication to reduce sex drive) a condition of parole for a long-term offender convicted of sexual assault. ${ }^{38}$

As with duress, undue influence invalidates consent in a manner that is grounded in the concept of coercion. In Norberg $v$ Wynrib, La Forest J. defined undue influence as "an illegitimate use of power or unlawful pressure which vitiates a person's freedom of choice." 39 Again it is important to take note of the qualifier "illegitimate," i.e. without lawful authority or justification. While La Forest J. indicated that this doctrine will have to be developed and applied in a manner that takes account of "the factual context of each case," ${ }^{40}$ in Norberg he stated two qualifying criteria: 1) "an overwhelming power imbalance" (i.e., "a marked inequality in the respective powers of the parties") and 2) "exploitation" (i.e., manipulation of the vulnerable party for self-interested ends). While these statements were made in connection with sexual battery, one might reflect on whether or how the doctrine might have purchase in psychiatric treatment contexts, for instance in response to the conscription of patients for research where there is little or no benefit to the patient and considerable benefit to the physician.

\footnotetext{
${ }^{34}$ NS IPTA, s.7; P.E.I. Mental Health Act, RSPEI 1988, c M-6.1 [PEI MHA], s.5(5).

35 See (apart from the Deacon case, infra) Stewart v. Postnikoff, 2014 BCSC 707 (CanLII). Mark Lunney and Ken Oliphant discuss a similar line of analysis in the UK jurisprudence, noting that the judgment in Freeman v Home Office (no 2) [1984] QB 524 “upheld a prisoner's apparent consent to medical treatment, ruling that the institutional pressures acting on the prisoner's mind did not affect the genuineness of that consent." (Tort Law: Texts and Materials, $5^{\text {th }}$ ed (Oxford: Oxford University Press, 2013) at 84.

${ }^{36}$ Deacon v. Canada (Attorney General), [2007] 2 FCR 607, 2006 FCA 265 (CanLII). See also R. v. Payne, 2001 CanLII 28422 (ON SC) at paras 138-139.

${ }^{37}$ Under its statutory mandate, the Board is to impose conditions of parole that are "reasonable and necessary in order to protect society and to facilitate the successful reintegration into society of the offender." (Corrections and Conditional Release Act, SC 1992, C 20, s.134.1(2)).

${ }^{38}$ Under the long-term offender designation (different from the status of "dangerous offender" which designates an indeterminate period of incarceration), prisoners are eligible for community release after serving their full sentence, but they must adhere to conditions imposed by the parole board for up to 10 years. See Criminal Code, s.753.1; HMTQ v. Gibbon, 2005 BCSC 935 (CanLII) at para 114.

${ }^{39}$ Norberg v. Wynrib, [1992] 2 S.C.R. 226 per La Forest J at 246, citing George B Klippert, Unjust Enrichment (Toronto: Butterworths, 1983) at 156.

${ }^{40}$ Noberg v. Wynrib, ibid at 246.
} 
A further twist on the doctrine of undue influence has involved arguing systemic vitiation of consent in an institutional environment marked by an extraordinary imbalance of power. Such a claim was advanced in Joanisse v. Barker. ${ }^{41}$ This was an application for certification of a class action based in subjection to forensic psychiatric hospital programming alleged to have featured experiments involving "solitary confinement, sensory deprivation, humiliation, force, restraints (cuffs), the use of hallucinogens and delirium-producing drugs and other forms of physical and mental abuse, under the guise of [the supervising psychiatrists'] "science"." Drawing on Norberg, the plaintiffs sought to advance as a common issue the question of whether genuine, voluntary consent was precluded by the coercive conditions in the facility. Although the judge rejected the certification bid on the ground that the genuineness of consent must be determined on an individualized basis, he observed that there was a sufficient evidentiary foundation on which to argue that the coercive institutional conditions had systematically undermined valid consent. ${ }^{42}$

All of the above notwithstanding, there are two exceptions at common law to the requirement of consent to medical treatment: emergency and public necessity.

At common law, medical treatment provided without consent does not constitute a battery where it "is necessary to save the life or preserve the health of a person who, by reason of unconsciousness or extreme illness, is incapable of either giving or withholding consent." 43 Kaiser has argued that the emergency exception, which arose in connection with cases involving persons in unconscious or barely conscious states (and in clear need of therapeutic intervention in order to preserve life or prevent "serious and permanent physical impairment"), is wholly inapplicable to the mental disability setting. ${ }^{44}$ However, certain statutes allow for emergency treatment in response to mental health crisis where incapacity and a severe risk to health are in place. ${ }^{45}$ That said, the determination of

\footnotetext{
${ }^{41} 2003$ Canlii 25791 (court file no 00-CV-199551CP).

${ }^{42} \mathrm{Ibid}$ at para 30. "There seems no doubt that at a trial of the common issues, the plaintiffs would be able to adduce expert evidence of the coercive effects of the environment in which the programs were conducted. In affidavits and reports filed on the motion, qualified psychiatrists provided opinions that support the position that a voluntary consent to participate in the programs was impossible."

${ }^{43}$ Malette v. Shulman, supra at para 20, citing Marshall v. Curry, [1933] 3 D.L.R. 260, 60 C.C.C. 136 (N.S.S.C.); Parmley v. Parmley, [1945] 4 D.L.R. 81, [1945] S.C.R. 635; Mulloy v. Hop Sang, [1935] 1 W.W.R. 714 (Alta. C.A.). More robust criteria are relayed in a passage from Prosser \& Keeton on Torts that is cited by the Ontario Court of Appeal in Malette v Shulman -- for instance, there, the exception is limited to situations where intervention is necessary to prevent "serious bodily injury or death" (at para 20). ${ }^{44}$ Archie Kaiser, "Mental Disability Law" Chapter 8 in Canadian Health Law and Policy, $2^{\text {nd }}$ ed (Markham: Butterworths, 2002) 251 at 295.

${ }^{45}$ See, e.g., Ontario's Health Care Consent Act, which provides for "emergency treatment" where an individual who is incapable of a decision about a prospective treatment is "apparently experiencing severe suffering or is at risk, if the treatment is not administered promptly, of sustaining serious bodily harm": HCCA, s.25(1) \& (2). More explicitly inclusive of mental health-based "emergency" is the Northwest Territories Mental Health Act, which authorizes "emergency medical or psychiatric treatment" (contingent on incapacity and lack of timely access to a substitute), where the treatment is "necessary to preserve the life or mental or physical health" of the person, and where a delay in treatment "would create a reasonably foreseeable risk of injury to that person or any other person." Mental Health Act, RSNWT 1988, c M-10, [NWT MHA], s.20(1)(c). Distinct provisions authorizing use of restraints / means of control are cited in note $y$, infra.
} 
incapacity required both at common law and under such statutory provisions is arguably likely to be impossible or near impossible to make in the context of a crisis. ${ }^{46}$ Moreover, it is highly questionable whether the conventional institutional responses to mental health crisis (use of physical or chemical restraints or seclusion) could be characterized as "therapeutic". 47

The common law defence more likely to be raised in efforts to justify forcible confinement or restraint is that of "public necessity." 48 This defence is expressly aimed at permitting the use of force to protect third parties - or potentially (here the law is murkier, and more starkly at odds with the right to medical self-determination) the person him or herself.

The legality of protective measures aimed at control was addressed by the Supreme Court of Canada in Wellesley Hospital v. Lawson. ${ }^{49}$ In that case, a non-psychiatric patient sued a hospital after he was injured by a psychiatric patient. The majority stated that the hospital owed "an independent duty to supervise and keep under reasonable control patients who the hospital knows or ought to have known have propensities to violent behaviour." 50

This reasoning was relied upon, and apparently extended, in Conway v. Fleming. ${ }^{51}$ There, Conway's claim for battery and breach of s.7 Charter rights arising out of subjection to seclusion and chemical restraints was rejected on the basis that the common law supported

a right and a duty to restrain Conway when necessary to protect him, other patients, or others lawfully on the premises (staff or other patients) from harm and to prevent endangerment to the safe environment of the hospital or facility. ${ }^{52}$

The extension of the doctrine of public necessity to permit the use of chemical restraints or seclusion to protect an individual against him or herself stands in marked tension with the circumscribed terms of the emergency exception. It moreover stands in tension with the insistence in the wider jurisprudence on respect for capable (even foolish or highly risky) choices. However, statutory mechanisms in some mental health laws contemplate

\footnotetext{
${ }^{46}$ On the challenges to health professionals' judgments in relation to "emergency modalities" including modalities of control (i.e physical and chemical restraints and seclusion), see Elyn R. Saks, Refusing Care: Forced Treatment and the Rights of the Mentally Ill (Chicago: University of Chicago Press, 2002) at 164172.

${ }^{47}$ See Kaiser, "Mental Disability Law" supra note x at 296.

${ }^{48}$ See Linden \& Feldthusen, supra note $\mathrm{x}$ at 99 : "Public necessity involves the interference with private rights in order to preserve the interests of the community at large". The defence of protecting third parties may apply where the rationale for intervention is "to save others from danger" (ibid at 97).

491977 CanLii 29 (SCC), [1978] 1 SCR 893.

${ }^{50}$ Ibid at 899.

51 [1996] OJ No 1242 (Div Ct) (QL) aff'd (1999) 1999 CanLii 19907 (On SC), 43 OR (3d) 92, 173 DLR $\left(4^{\text {th }}\right) 372$ (On CA).

${ }^{52}$ Ibid at para 278.
} 
just such a contingency. ${ }^{53}$ These mechanisms vary, with some requiring a threat of bodily harm ${ }^{54}$ to the individual or another, and others only a risk of "harm"; 55 most articulate a standard of "least restrictive means" and some require formal documentation of the use of restraints. ${ }^{56}$

The case law does not set clear or precise limits on the common law authority to restrain. ${ }^{57}$ However, an essential part of the defence of public necessity (and the related defence of protection of third parties) is that the one acting to protect must act reasonably, ${ }^{58}$ weigh the proportionality of the response against the risk, ${ }^{59}$ and otherwise contain the threatening behaviour in the least restrictive manner possible. ${ }^{60}$ Given evidence amassed in recent years about the significant risks associated with use of restraints (physical, chemical and environmental), ${ }^{61}$ these justificatory requirements pose

53 See Mental Health Act, RSPEI 1988, c M-6.1, s.24(12) ("psychiatric treatment" for the purpose of "keep[ing] the patient under control"); Alberta Mental Health Act, s.30; Manitoba Mental Health Act, s.1 \& 29(4); Nunavut / Northwest Territories Mental Health Act, s.36.1; Yukon Mental Health Act, s.18; Ontario Mental Health Act, s.1(1) ("restrain") and s.53.

54 Ontario's Mental Health Act authorizes actions to place a patient "under control when necessary to prevent serious bodily harm to the patient or to another person by the minimal use of such force, mechanical means or chemicals as is reasonable having regard to the physical and mental condition of the patient" (s.1(1)). Section 14 of Ontario's MHA further states that nothing in it "authorizes a psychiatric facility to detain or to restrain an informal or voluntary patient”. See M (Re), 2009 CanLII 45568 (ON $\mathrm{CCB})$.

55 Section 1(1) of Manitoba's MHA defines "restrain" as to "place under control when necessary to prevent harm to the patient or to another person" (and see s.29(4)). Section 24(12) of PEI's MHA permits the use of psychiatric medication or restraints "in order to keep the patient under control and to prevent harm to the patient or to another person."

56 See, e.g., Ontario MHA, s. 1(1) \& s. 53; Nunavut / Northwest Territories MHA, s.36.1(2); Manitoba MHA, s.1 ("restrain") \& s.29(4).

57 There are a few statements of note in this connection in Hneihen v. Centre for Addiction and Mental Health 2014 ONSC 55 (CanLII), 301 C.R.R. (2d) 124, e.g., at para 78: "The defense of public necessity is available for certain narrowly defined situations of "imminent peril" (citing John Murphy, Christian Witting \& James Goudkam Street on Torts, $13^{\text {th }}$ ed. (Oxford: Oxford University Press, 2012), para. 24 at p. 340; Linden \& Feldthusen, supra note $\mathrm{x}$ at 99.

${ }^{58}$ See Linden \& Feldthusen, supra note $\mathrm{x}$ at 97.

${ }^{59}$ Simon Verdun-Jones \& Michelle Lawrence, supra note $\mathrm{x}$ at 520, propose that the standard for intervention should be "imminent danger to the safety" of the patient or third parties, and that it is necessarily implicit that "the forcible administration of medication also must be delivered with reasonable skill and care and represent the least intrusive option available." Finally, they note that the defence should justify continuing the involuntary intervention only "so long as there is a genuine threat of violence or aggression." (520-21).

${ }^{60}$ Kaiser, "Mental Disability Law" supra note x at 297. Kaiser adds that "non-statist alternatives" [i.e, "[p]rofessional standards and practices, hospital accreditation policies, coroner (and related) reports, the media and advocacy organizations"] "can assist in reducing or eliminating the practice of restraint and seclusion". See also H.A. Kaiser, "Restraint and Seclusion in Canadian Mental Health Facilities: Assessing the Prospects for Improved Access to Justice” (2001) 19 Windsor Yearbook of Access to Justice 391. And see Registered Nurses' Association of Ontario, Promoting Safety: Alternative Approaches to the Use of Restraints (Toronto: Registered Nurses’ Association of Ontario, 2012).

${ }^{61}$ Wanda K Mohr et al, "Adverse Effects Associated with Physical Restraint" Canadian Journal of Psychiatry (June 2003) https:/ww1.cpa-apc.org/Publications/Archives/CJP/2003/june/mohr.asp; US General Accounting Office. Mental health: improper restraint or seclusion use places people at risk. (GAO publication HEH-99-176). Washington (DC): USGAO; 1999; B.C. Dickson \& M.S. Pollanen, "Case Report: Fatal thromboembolic disease: A risk in physically restrained psychiatric patients" (2009) 16(5) 
a high bar likely only to be met by an imminent risk of serious bodily harm. ${ }^{62}$

\section{Informed Consent}

The second of the three core elements of valid health care consent is that the decision be informed. ${ }^{63}$ Failure to adequately inform one who is facing the prospect of a medical intervention may give rise to liability in negligence. ${ }^{64}$ There are two primary steps to a negligence action of this type. First, the plaintiff must establish inadequate disclosure, i.e., breach of the standard of care. Second, the plaintiff must prove that the failure to disclose caused compensable injury. ${ }^{65}$ It is at the causation stage that persons seeking damages for breach of the duty of disclosure most commonly fail. ${ }^{66}$

While the duty of disclosure is rooted in law and in the value of autonomy, it has also been argued to produce therapeutic benefits. That is, enabling individuals to learn about, reflect upon and form opinions about their therapeutic options increases the likelihood that the approaches adopted will be responsive to their needs and experienced as enhancing well-being. ${ }^{67}$

\section{Disclosure}

The duty of disclosure requires that health professionals

Journal of Forensic and Legal Medicine 284; R. Gallop et al, "The experience of hospitalization and restraint of women who have a history of childhood sexual abuse," (1999) 20 Health Care for Women International 401; Secure Rooms and Seclusion Standards and Guidelines: a Literature and Evidence Review (BC Ministry of Health, September 2012) at 9; D.K. Knox \& G.H. Holloman, "Statement of the American Association for Emergency Psychiatry Project BETA Seclusion and Restraint Workshop" (2012) 13(1) West J Emerg Med. 35-40.

${ }^{62}$ See Verdun-Jones \& Lawrence, supra note $\mathrm{x}$ at 520; Kaiser, "Restraint and Seclusion in Canadian Mental Health Facilities: Assessing the Prospects for Improved Access to Justice" supra note x. The 2013 Report of the UN Special Rapporteur on Torture observes that, given the absence of therapeutic justification, the use of restraints or "prolonged seclusion . . cannot be legitimate under the medical necessity doctrine," and may "constitute torture and ill-treatment" under the UN Convention. The Report calls for "an absolute ban on all coercive and non-consensual measures, including restraint and solitary confinement of people with psychological or intellectual disabilities," in "all places of deprivation of liberty, including in psychiatric and social care institutions" (Human Rights Council, UN Doc A/22/53, (Feb 1, 2013)). See also Torture in Healthcare Settings: Reflections on the Special Rapporteur on Torture's 2013 Thematic Report (American University Washington College of Law Centre for Human Rights and Humanitarian Law, 2014) (http://antitorture.org/wp-content/uploads/2014/03/PDF Torture in Healthcare Publication.pdf).

${ }^{63}$ This common law right is also reflected in legislation. See, e.g., BC's HCCFAA, supra note x, s.6(e)\&(f) and Ontario's HCCA, supra note x, s.11(1)-(3).

${ }^{64}$ Reibl v. Hughes [1980] 2 S.C.R. 880.

${ }^{65}$ This is more properly conceived as two distinct elements: proof of compensable damage and proof of causation. However, I have opted for simplicity in this brief discussion.

${ }^{66}$ See Gerald Robertson, "Informed Consent 20 Years Later" (2003) Health Law Journal 153.

${ }^{67}$ See e.g. Bruce J Winick, The Right to Refuse Mental Health Treatment (Washington, DC: American Psychological Association, 1997) at 338-42, and Bruce J. Winick, "The MacArthur Treatment Competence Study: Legal and Therapeutic Implications" (1996) 2:1 Psychology, Public Policy, and Law 137. 
ensure the patient understands the nature of the procedure, its risks and benefits, and the availability of alternative treatments before making a decision about a course of treatment. ${ }^{68}$

This implies disclosure of all "material risks" 69 including high-probability/low magnitude and low probability/high magnitude risks. ${ }^{70}$ The health professional must also answer any specific questions from the patient relating to the treatment. ${ }^{71}$

In presenting alternative treatments, the health professional must include the alternative of non-treatment. ${ }^{72}$ The expectation that alternatives will be disclosed is even greater where the alternatives carry fewer risks than the primary intervention under consideration. ${ }^{73}$ Some judges have restricted the requirement to disclose alternatives to those falling within the physician's own clinical expertise. ${ }^{74}$ Others have adopted the moderately higher standard of disclosure of those "options that in [the physician's] reasonable medical judgment are appropriate for the patient." 75 In a further modification of the standard, the Ontario Court of Appeal has recently stated that a physician must advise the patient of all alternatives identified through the exercise of reasonable medical judgment -- including those the physician regards as likely to be less efficacious in the circumstances. $^{76}$

What constitutes reasonable medical judgment may be a matter of contention. Yet it is arguable, for instance, that adequate disclosure about treatment options for depression or anxiety (two of the most prevalent and highly medicated of any health conditions in North America) should include discussion of psychotherapy, given strong evidence of the

\footnotetext{
${ }^{68}$ Cuthbertson v. Rasouli, 2013 SCC 53, [2013] 3 SCR 34 at para 18.

${ }^{69}$ Hopp v. Lepp, 1980 CanLII 14 (SCC), [1980] 2 SCR 192 at 210. The passage states in addition the requirement to disclose "any special or unusual risks attendant upon" the proposed intervention.

${ }^{70}$ Hopp v. Lepp, ibid at p.209-210, and see Hollis v. Dow Corning Corp., [1995] 4 SCR 634, 1995 CanLII 55 (SCC) at para 24. Also see the decision of McLachlin J in Rawlings v. Lindsay, [1982] BCJ No 209, 20 CCLT 301 at 306.

${ }^{71}$ Hopp v. Lepp, ibid at 210.

72 See Zimmer v. Ringrose, 1981 ABCA 60 (CanLII), 124 D.L.R. (3d) 215 at para. 16 (CA); Haughian v. Paine, 1987 CanLII 987 (SK CA) at p.26. In the latter case, the Saskatchewan Court of Appeal determined that a physician had breached the duty of disclosure in failing to advise adequately, or at all, of the available options of no treatment, or conservative management. While it may have been open to the respondent not to recommend these options by way of treatment, the patient was entitled to be advised that these alternatives were open to him. (para 38)

${ }^{73}$ Kern v. Forest, 2010 BCSC 938.

${ }^{74}$ See Bafaro v. Dowd, 2008 CanLII 45000 (ON SC), at para 42, citing Sanders v. Sheridan, [2000] S.J. No. 403 (Q.B.): ("The Courts have held that where a physician feels a particular procedure is clinically not an option for him to perform on the patient, the physician does not have a duty to provide the option")

${ }^{75}$ Van Dyke v. Grey Bruce Regional Health Centre [2005] OJ No 2219 (On CA) leave to appeal refused [2005] SCCA No 335 (SCC) at para 65 citing Bucknam v. Kostiuk (1983), 1983 CanLII 1865 (ON SC), 44 O.R. (2d) 102 at 114 (HCJ), aff'd (1986), 1986 CanLII 2686 (ON CA), 55 O.R. (2d) 187 (CA).

${ }^{76}$ See Van Dyke v. Grey Bruce Regional Health Centre, ibid at para 66, and Patricia Peppin, "Informed Consent" in J. Downie, T. Caulfield \& C. Flood, eds., Canadian Health Law and Policy, 3rd ed. (Markham, Ont.: Butterworths, 2007) 153 at 165-166.
} 
relative efficacy and safety of this alternative. ${ }^{77}$ In accordance with the above-noted statements of the Ontario Court of Appeal, this should hold whether or not the health professional is personally equipped to provide this alternative or is convinced of its relative efficacy. ${ }^{78}$

Even where individuals are subject to involuntary treatment, legislation may require physicians to inform patients of the nature and risks of treatment and to take the patient's views into consideration. ${ }^{79}$ However, these statutory obligations are markedly truncated in comparison with the common law duty to inform.

Turning to common law exceptions to the duty to inform, there is a possibility that health professionals in psychiatric treatment settings may rely (with what they believe to be legal justification) on the highly questionable category of exemption from disclosure known as therapeutic privilege. In Reibl v. Hughes,${ }^{80}$ Laskin C.J. briefly adverts to this doctrine, which he indicates has been recognized in U.S. law:

It may be the case that a particular patient may, because of emotional factors, be unable to cope with facts relevant to recommended surgery or treatment and the doctor may, in such a case, be justified in withholding or generalizing information as to which he would otherwise be required to be more specific. ${ }^{81}$

This principle was restated the following year in the Ontario Court of Appeal's decision in Videto et al v. Kennedy ${ }^{82}$ There, it was said that an individual's "emotional condition"

\footnotetext{
${ }^{77}$ American Psychological Association, "Recognition of Psychotherapy Effectiveness" (approved August 2012) at http://www.apa.org/about/policy/resolution-psychotherapy.aspx; S. De Maat et al, "Relative efficacy of psychotherapy and pharmacotherapy in the treatment of depression: A meta-analysis" (2006) 16:5 Psychotherapy Research 566; G. Speilmans et al, "Psychotherapy versus second-generation antidepressants in the treatment of depression: a meta-analysis" (2011) 199 Journal of Nervous and Mental Disease 142. See also John Huntsley et al, "The Effectiveness and Efficiacy of Psychological Treatments (Canadian Psychology Association, Sept 2013), and L.A. Pratt, D.J. Brody \& Q. Gu, "Antidepressant use in persons aged 12 and over: United States, 2005-2008" NCHS data brief no 76 (Hyattsville, MD: National Center for Health Statistics, 2011).

${ }^{78}$ In some circumstances there may be a dispute about whether psychotherapy falls within the appropriate standard of care. See the US case Morris v. Ferriss, 669 So.2d 1316, 1996, where the judge found that psychotherapy was not an appropriate treatment for the plaintiff's "organically based" condition, such that there was no duty to discuss this alternative.

${ }^{79}$ For example, section 25(3) of the Saskatchewan MSHA, supra note x, provides that even where treating an involuntarily detained patient without consent in accordance with the Act, the attending physician shall, to the extent that it is feasible given the patient's medical condition, [...] consult with the patient, explain or cause to be explained to the patient the purpose, nature and effect of proposed diagnosis or treatment and give consideration to the views the patient expresses concerning the patient's choice of therapists, the proposed diagnosis or treatment and any alternatives and the manner in which diagnoses or treatments may be provided.

${ }^{80}$ [1980] 2 SCR 880, 1980 CanLII 23 (SCC)

${ }^{81}$ Ibid at 895 .

82 (1981), 1981 CanLII 1948 (ON CA), 17 C.C.L.T. 307
} 
and/or his or her "apprehension and reluctance to undergo" 83 a prescribed procedure may warrant non-disclosure.

At least one judge has observed that the doctrine of therapeutic privilege sits uneasily with the respect for autonomy underlying the right to choose and refuse treatment, and has refused to recognize the doctrine.${ }^{84}$ Commentators, too, have suggested that the doctrine is, if a valid common law defence to non-disclosure at all, then one that stands "on narrow and shaky grounds." 85 Arguably, the doctrine ought to be rejected in favour of a duty to ensure that information is relayed in a manner that is compassionate and as supportive as possible of careful, critical deliberation -- no matter what the person's diagnosed health condition or mental state. ${ }^{86}$

It is notable that the law on disclosure does not compel dialogue about what might be termed structural risks -- for example, systemic post-market underreporting of adverse drug events, unrepresentativeness of the research subjects in pre-market clinical trials, or industry suppression of negative clinical trial results. ${ }^{87}$ Nor does the law mandate discussion of alternative, critical understandings of conditions or diagnoses (whether schizophrenia, depression, or feminine sexual dysfunction) ${ }^{88}$ These matters fall within the purview of bioethics and social critique rather than law. Law, for its part, maintains a careful attitude of deference toward medical norms and judgment, even while anchoring disclosure obligations in the circumstances of the particular patient. Is there a role for law in constructing conditions more conducive to critical deliberation about one's values and therapeutic options - and so more promoting of medical self-determination?

\footnotetext{
${ }^{83}$ Ibid at 315-16: "The emotional condition of the patient and the patient's apprehension and reluctance to undergo the operation may in certain cases justify the surgeon in withholding or generalizing information as to which he would otherwise be required to be more specific"

${ }^{84}$ See Meyer Estate v. Rogers (Gen. Div.), (1991) 2 OR (3d) 356; [1991] OJ No 139 (QL)

(ON SC) (Section 4: "Conclusions on Therapeutic Privilege"): "The doctrine has no place in the law on consent in Canada; rather, it has the potential to ""swallow" the doctor's obligation of disclosure and thus to override the requirement for informed consent".

${ }^{85}$ Patricia Peppin, "Informed Consent" supra note x at 174; Archie Kaiser, "Mental Disability Law" supra note $\mathrm{y}$ at 297.

${ }^{86}$ Mitchell Law Corporation et al, 015 MBQB 88 (CanLII), (Docket CI 12-01-77745) (relying on McInerney v MacDonald, [1992] 2 SCR 138, 1992 CanLII 57 (SCC), the judge recognizes a continuing role for the doctrine of therapeutic privilege in Canadian law, yet limits its application in the case at hand to giving support to a duty to disclose the relevant information in a "constructive" manner (at paras 141-142, $146,167,169,175)$.

${ }^{87}$ See, e.g., Ben Goldacre, Bad Pharma: How Medicine is Broken, and How We Can Fix It (London: Fourth Estate, 2012).

${ }^{88}$ See e.g., Mary Boyle, Schizophrenia: A Scientific Delusion? (London and New York: Routledge, 1990); Joanna Moncrieff \& Hugh Middleton, "Schizophrenia: A Critical Psychiatry Perspective" (2015) 28(3) Curr Opin Psychiatry 264; David Pilgrim \& Richard Bentall, "The medicalization of misery: A critical realist analysis of the concept of depression" (1999) 8(3) Journal of Mental Health 261; Alyson K. Spurgas, "Interest, Arousal, and Shifting Diagnoses of Female Sexual Dysfunction, or: How Women Learn About Desire" (2013) 14 Studies in Gender and Sexuality 187; Lisa Cosgrove, "The DSM, Big Pharma, and Clinical Practice Guidelines: Protecting Patient Autonomy and Informed Consent" (2011) 4:1 International Journal of Feminist Approaches to Bioethics, Special Issue: Feminist Perspectives on Ethics in Psychiatry 11 esp at 14-17.
} 


\section{Causation}

As stated in Arndt v. Smith, ${ }^{89}$ the test for causation in medical negligence cases involving failure to disclose is an objective ${ }^{90}$ one, which

requires that the court consider what the reasonable patient in the circumstances of the plaintiff would have done if faced with the same situation. The trier of fact must take into consideration any "particular concerns" of the patient and any "special considerations affecting the particular patient" in determining whether the patient would have refused treatment if given all the information about the possible risks. $^{91}$

This test has proven a steep challenge for plaintiffs, as judges often conclude that a reasonable person in the plaintiff's position ${ }^{92}$ would have deferred to the health professional's recommendations to proceed even if the requisite risks or alternatives had been disclosed.$^{93}$ This reasoning may render legally irrelevant individual characteristics such as a tendency to adopt a suspicious, rather than trusting, relationship with health providers, or a sustained interest in exploring alternatives to medication.

\section{Capable Consent}

\section{Decision-making capacity at common law and in mental health / health care consent laws}

The last of the three essential requisites of valid consent is capacity.

\footnotetext{
${ }^{89}$ [1997] 2 SCR 539.

90 See Vaughan Black and Dennis Klimchuk, "Comment on Arndt v. Smith” (1997) 76 Canadian Bar Review 569 for a critique of the concept "modified objective test" used by Cory J in Arndt v Smith, ibid, and the argument that Cory $\mathrm{J}$ states no compelling justification for rejecting a subjective test for causation. Of particular relevance is the authors' critique of Justice Cory's repeated depiction of the plaintiff in this type of action as irrational and unreliable - and in particular, as harbouring unaccountable concerns about risk (e.g., a belief that a temporary red rash on the skin is a "highly significant and dangerous sign of evil spirits in the body" (at para 14)). As Black and Klimchuk point out, similar concerns said to warrant rejection of a subjective test of causation do not arise in the jurisprudence addressing failure to disclose in commercial contexts.

${ }^{91}$ Arndt v. Smith, supra note x per Cory $\mathrm{J}$ at para 6, summarizing the standard for causation specific to actions in negligence arising out of failure to disclose in the doctor-patient relationship, from Reibl $v$. Hughes, [1980] 2 SCR 880, 1980 CanLII 23 (SCC).

92 According to Cory J, the trier of fact must take into account any "particular concerns" of the patient and "any special considerations affecting the particular patient," as such "the patient's reasonable beliefs, fears, desires and expectations" (Arndt $v$ Smith, supra note $\mathrm{x}$ at para 9).

93 See Gerald Robertson, "Informed Consent 20 Years Later" (2003) Health Law Journal (Special Edition) 153. Robertson argues, however, that one effect of Reibl v Hughes may have been to shift clinical practice toward greater disclosure. That is, while plaintiffs continue to lose most often at the causation stage, Robertson suggests that the case law since Reibl is marked by an increase in the proportion of cases in which doctors are determined to have met the duty of disclosure. (at 155)
} 
The capacity to make decisions about health care is framed at common law and in legislation as decision-specific as well as time-sensitive (such that capacity status may fluctuate).$^{94}$ In Cuthbertson v. Rasouli, McLachlin CJ for the majority stated:

The common law doctrine of informed consent "presupposes the patient's capacity to make a subjective treatment decision based on her understanding of the necessary medical facts provided by the doctor [i.e., "the nature, purpose, and consequences of the proposed treatment"] and on her assessment of her own personal circumstances". When such capacity is lacking, the patient is not in a position to exercise his autonomy by consenting to or refusing medical treatment. $^{95}$

That is to say that the doctrine of informed consent carries the implicit expectation that the individual is able to understand the matters disclosed and apply them to his or her own case. Where this ability, or capacity, is lacking, consent is invalid and the consequence is that the intervention constitutes a battery (subject to an alternative defence). McLachlin CJ's description of the common law expectations of decisionmaking capacity resembles the prevailing approach adopted in provincial and territorial health care consent and mental health legislation, which typically speaks to the ability to "understand" and to "appreciate" 96 the matters of primary relevance to the decision. As Sophie Nunnelly notes in chapter X, the three provinces that make incapacity to make treatment decisions a condition of involuntary hospitalization (and treatment) ${ }^{97}$ elevate the standard beyond that which applies in other health care contexts and require the ability to "fully" understand and appreciate the matters in issue. .9

All adults are presumed to have legal capacity to make medical decisions at common law - and the onus lies on the one challenging capacity to rebut this presumption. ${ }^{99}$ Health

\footnotetext{
${ }^{94}$ See Michael Bach \& Lana Kerzner, A New Paradigm for Protecting Autonomy and the Right to Legal Capacity (Law Commission of Ontario, October 2010) at 47-49.

952013 SCC 53, [2013] 3 S.C.R. 341 at paras 19-21, citing Malette v Shulman (1990), 72 OR (2d) 417 (CA) at pp 423-24. Italics added.

${ }^{96}$ See, e.g., Ontario HCCA, supra note x, s.4(1); Substitute Decisions Act, 1992, S.O. 1992, c. 30, ss. 6, 45; The Adult Guardianship and Co-decision-making Act, SS 2000, c A-5.3, s 2(c); The Vulnerable Persons Living with a Mental Disability Act, CCSM c V90, ss 46, 81 [applies only in respect of adults with a mental disability manifesting before age 18, and not to persons coming under the jurisdiction of Manitoba's Mental Health Act]; Mental Health Act, CCSM c M110, s 27(2); Adult Guardianship and Trusteeship Act, SA 2008, c A-4.2, s.1(d); Mental Health Act, RSA 2000, c M-13, s. 26; Hospitals Act, RSNS 1989, c 208, s.52(2A).

${ }^{97}$ These are Saskatchewan, Nova Scotia and Newfoundland (see note $\mathrm{x}$, supra [citing the three Acts on this point]).

${ }^{98}$ Nova Scotia's Act requires the ability to "fully" understand and appreciate the matters relating to admission to and treatment in psychiatric hospital (Nova Scotia IPTA, supra note x, s.18). The province's Hospitals Act, supra note y (which applies to all hospital patients except for involuntary psychiatric patients) states the same criteria, but for the requirement that the individual be able to fully understand and appreciate the matters of relevance. See also Saskatchewan MHSA, supra note x, s.24(2)(ii), and Newfoundland's MHCTA, supra note x, s.17(1)(b)(ii)(B).

${ }^{99}$ See Gligorevic v. McMaster (2012), 109 OR (3d) 3212012 (CA), ONCA 115 (CanLII) at para 59; Khan v. St. Thomas Psychiatric Hospital (1992), 52 OAC 166, 1992 CanLII 7464 (ON CA); Starson v Swayze, supra note $\mathrm{x}$ at para 77. See also Ontario's HCCA, supra note x, s.4(2). The Ontario Court of Appeal has
} 
care consent legislation typically places responsibility for evaluating capacity upon regulated health professionals. ${ }^{100}$ At common law, the fact that capacity is an essential element of valid consent suggests that all health care practitioners must be mindful of capacity when seeking consent within their scope of practice.

\section{Interpreting and applying the law - Starson}

The law on capacity to make treatment decisions in psychiatric treatment settings was addressed in a 2003 Supreme Court of Canada judgment, Starson v. Swayze. ${ }^{101}$

Starson had been placed involuntarily in a psychiatric hospital following a verdict of not criminally responsible by reason of mental disorder (on charges of uttering threats). His diagnosis was "bipolar disorder with psychotic features."102 He refused neuroleptic medication, mood stabilizers, anti-anxiety medication and anti-parkinsonian medication, and was found by his psychiatrist to be incapable of making decisions about these treatments.

In the ensuing hearing before the Consent and Capacity Board, Starson argued 1) that while he acknowledged that aspects of his thinking and behaviour were consistent with the diagnosis of bipolar disorder, he valued these aspects of himself; ${ }^{103}$ and 2) that there was no basis on which to expect that the proposed treatments would benefit him (i.e., no prospective benefits that he should be expected to "understand" and "appreciate"). ${ }^{104}$ Rather, he argued, past anti-psychotic treatments had negatively affected his well-being (in particular, his ability to think and express himself); moreover, the primary intended effect of the medication (aimed at "slow[ing] down his thoughts") would in his view be inferior to his untreated state. ${ }^{105}$ Starson's enthusiasm for his unusual thought processes was based in part in his belief that these were essential to contributions he had made in theoretical physics. His doctors took a dimmer view, with one suggesting that Starson,

stated, in connection with disputes about incapacity under the HCCA an expectation of "strong and unequivocal evidence" on the part of the one bearing the onus (Gligorevic v. McMaster ibid at para 60). See also Manitoba's Mental Health Act, CCSM c M110, s.2 (stating a presumption that persons 16 and over are capable of making treatment decisions under the Act, while persons under 16 are presumed incapable); BC's HCCFAA, supra note x, s.3(1); Nova Scotia's Hospitals Act, RSNS 1989, c 208, s.52(1) [applies to decisions about health care in hospital, except for involuntary psychiatric patients in respect of psychiatric treatment, s.71A]; PEI's Consent to Treatment and Health Care Directives Act, RSPEI 1988, c C-17.2, s.3(1); Alberta's Personal Directives Act, RSA 2000, c P-6, s.3(2) (presumption applies to those who are at least 18 years of age).

${ }^{100}$ Ontario HCCA, supra note x, s.2(1) ("health practitioner") \& s.10(1); BC HCCFAA, supra note x, s.1 ("health care provider") \& s.7; but see Nova Scotia's Hospitals Act, s.2(r) ("psychiatrist") \& 52(2). In mental health legislation, this obligation is placed on the attending physician or psychiatrist: Alberta MHA, supra note x, s.27(1) (physician); Manitoba MHA, supra note x, s.27(1) (attending physician).

${ }^{101}$ [2003] 1 SCR 722, 2003 SCC 32 (CanLII).

102 Ibid, per McLachlin CJ at para 20.

${ }^{103}$ Ibid at paras 93-95, 102 (per Major J).

${ }^{104}$ Ibid at paras 92, 98-99, 101-102. The majority also found that, apart from the "scant evidentiary basis" from which to conclude that Starson's condition was likely to deteriorate without the proposed treatments, he "was never asked at the hearing whether he understood the possibility that his condition could worsen without treatment." (at para 105).

${ }^{105}$ Ibid at paras 98-99, 102. 
who "could have made an enormous contribution to society," was "lost in a psychotic world." 106 That said, there was some ambivalence in the medical testimony as to whether Starson's condition was likely to worsen without treatment. ${ }^{107}$

The Board upheld the psychiatrist's declaration of incapacity on the basis that Starson "was in 'almost total' denial of a mental disorder," and that, as a result, he "failed to appreciate the consequences of his decision." 108 They concluded that because he could not "relate information to his own particular disorder," he could not "understand the consequences of a decision to either refuse or consent to medication." 109

The Board's decision was overturned by the Ontario Superior Court of Justice, in a decision upheld by the Court of Appeal and a majority of the Supreme Court of Canada. There was a marked division between the majority and dissenting reasons of the Supreme Court. Justice Major, writing for the majority, placed the dispute in the wider context of deep social prejudice against persons with mental health disabilities:

The tendency to conflate mental illness with lack of capacity, which occurs to an even greater extent when involuntary commitment is involved, has deep historical roots, and even though changes have occurred in the law over the past twenty years, attitudes and beliefs have been slow to change. For this reason it is particularly important that autonomy and self-determination be given priority when assessing individuals in this group. ${ }^{110}$

There was a basic level of agreement as between the majority and dissent on the meaning of the statutory criteria of "understanding" and "appreciation." That is, the first criterion "requires the cognitive ability to process, retain and understand the relevant information," and the second "requires the patient to be able to apply the relevant information to his or her circumstances, and to be able to weigh the foreseeable risks and benefits of a decision or lack thereof." 11 Yet the majority and dissenting opinions diverged in important respects on further aspects of the interpretation and application of the test.

Two key principles of precedential value were expressed by the majority of the Supreme Court in Starson. The first is advanced in three linked statements. First, one is not required to describe one's condition as an illness or to characterize it in negative terms, nor is one required to agree with a physician's opinion regarding its cause, in order to avoid a determination of incapacity. ${ }^{112}$ Second, if one demonstrates an appreciation of the information relevant to the decision (including the likely consequences of treatment or non-treatment), one will satisfy the criterion of appreciation, regardless of whether one

\footnotetext{
106 Ibid at para 44 (quoting Dr. Posner).

${ }^{107}$ Ibid at paras 103-104, per Major J. See also the different reading of the evidence on the part of McLachlin CJ, at paras $2 \& 4,28 \& 43-45$.

${ }^{108}$ Ibid at para 90.

${ }^{109}$ Ibid at para 70 .

${ }^{110}$ Ibid at para 77, citing D. N. Weisstub, Enquiry on Mental Competency: Final Report (Toronto: Publications Toronto, 1990) at 116.

111 Starson, ibid at para 78.

112 Ibid at para 79.
} 
disagrees with a physician's treatment recommendation. ${ }^{113}$ However -- and this is the third linked statement -- if one is unable (on being given a proper chance to demonstrate ability) to recognize that one is affected by one's condition, one is incapable of applying the relevant information about treatment and non-treatment to oneself and so of appreciating the consequences of one's decision. ${ }^{114}$

The first two statements express an imperative of respect for individuals' diverse values, even where those values diverge from those informing physicians' treatment recommendations. ${ }^{115}$ The lingering question, however, is how to distinguish dissident yet capable weightings of facts and foreseeable consequences from inability to appreciate these matters -- particularly where one's preferences appear to be deeply in conflict with one's interests. The third statement represents the Starson majority's effort to distinguish dissident but capable opinions about the value to be accorded the matters of relevance to treatment choice - including one's actual and anticipated mental/psychosocial condition, with and without treatment - from inability to recognize (and so appreciate) the relevant facts. Foremost among the matters requiring recognition is the fact that one "is affected" by the "manifestations" of one's diagnosed condition. Inability to do so means one cannot appreciate what is at stake in the treatment choice. In this way, the majority seeks to locate something other than competing values or normative judgments - some objective, empirically-grounded bedrock - on which to anchor incapacity.

The second (simpler) principle articulated by the Starson majority is that because capacity assessment aims at gauging ability, it is impermissible to infer incapacity simply from an individual's failure to demonstrate adequacy to the test. Rather, one must inquire into the reasons for this failure. Circumstances that might interfere with a demonstration of capacity include lack of information, sedation, ${ }^{116}$ transient emotional upset, ${ }^{117}$ or, one might speculate, deep opposition to the circumstances that have brought one to the point of capacity assessment.

The majority in Starson ultimately concluded, inter alia, that Starson's enthusiasm for his unusual manner of thinking qualified as a form of appreciation of his condition.

Moreover, it concluded that Starson's doctors had not established the likely benefits of treatment (i.e., benefits that Starson should be expected to "appreciate"). ${ }^{118}$

\footnotetext{
${ }^{113}$ Ibid at para 80 .

${ }^{114}$ Ibid at para 79.

${ }^{115}$ See George Crowder, Liberalism and Value Pluralism (London: Continuum Publishers, 2002). The majority judgment in Starson is arguably consonant with Crowder's account (at 197) of the three primary expressions of value pluralism within the liberal tradition: 1) "attention to the range and distinctiveness of values"; 2) "attention to the particularity of concrete situations"; and 3) "attention to the individual persons affected by one's decision". Crowder cites as exemplary of pluralist liberalism Isaiah Berlin's critique of "those versions of positive liberty that make it possible for leaders to 'ignore the actual wishes of men or societies, to bully, oppress, torture them in the name, and on behalf, of their 'real' selves." (Berlin, "Two Concepts of Liberty" in Four Essays on Liberty (Oxford: Oxford University Press, 1969) 118 at 133).

${ }^{116}$ Starson supra note $\mathrm{x}$ at para 15, citing the Weisstub Report, supra note $\mathrm{y}$ at 421-22.

${ }^{117}$ See Crewe (Re), 2007 NSSC 322 (CanLII), 259 NSR (2d) 273.

${ }^{118}$ Starson, supra note $\mathrm{x}$ at paras $95,102, \& 105-106$. It is important to note that the majority placed particular importance on the fact that Starson had acknowledged a need for some form of treatment (indeed, treatment in hospital) - i.e., a need for psychotherapeutic counseling. See paras $93 \& 105$.
} 
Chief Justice McLachlin in dissent endorsed the principles that transient circumstances should not prejudice the assessment of capacity, ${ }^{119}$ and that disagreement about one's diagnosis should not be determinative of incapacity. ${ }^{120}$ However, she parted ways with the majority on whether treatment refusal may be capable where it is based in denial of illness. ${ }^{121}$ Instead, she found that a lack of appreciation may be inferred from failure to regard objective symptoms as an illness (relevant to the proposed treatment). ${ }^{122}$ As Dull has argued, ${ }^{123}$ the dissent thus roots capacity in the concept of "insight" or awareness of one's symptoms as pathological. ${ }^{124}$ Thus, on the dissent's approach, evaluation of the ability to appreciate the matters of relevance to a treatment decision requires a judgment about the appropriateness of the individual's affective and evaluative responses to his or her condition and prospects. ${ }^{125}$ On this understanding, the primary flaw of the majority was its allowing that appreciation of one's condition may include "enthusiasm for objective symptoms." 126

Should it be possible, as the dissent in Starson suggests, to base a conclusion of incapacity on an individual's relative preference for his or her pathologized condition? Or is the conferring of such authority on medical personnel fundamentally at odds with the interest in medical self-determination?

Dull observes that lower courts have frequently departed from the majority's reasoning in Starson by superficially applying the principles stated by the majority while privileging those stated by the dissent, particularly the principle that "appreciation" requires acknowledgement that the symptoms associated with one's illness are problematic, along with recognition of one's need for treatment. ${ }^{127}$ The cases typically feature little or no

\footnotetext{
119 Starson, supra note $\mathrm{x}$ at paras 14-15 (per McLachlin CJ).

${ }^{120}$ Ibid.

${ }^{121}$ Ibid at para 27, per McLachlin CJ (citing the reasoning of the Board with approval).

${ }^{122}$ Starson, supra note $\mathrm{x}$ per McLachlin CJ (citing the reasoning of the Board with approval) at para 28 (italics added): The full statement is: "The Board never suggested that Professor Starson denied all his difficulties and symptoms; indeed, it expressly acknowledged this. The Board did suggest, entirely accurately, that Professor Starson did not see his symptoms and difficulties as an illness or a problem relevant to the proposals for treatment."

${ }^{123}$ Monique W. Dull, "Starson v. Swayze, 2003-2008: Appreciating the Judicial Consequences" (2009) 17 Health Law Journal 51. Dull examines the 13 court judgments during this period that followed or distinguished the reasoning in Starson.

${ }^{124}$ Ibid at 60, citing Ruth Macklin, "Some problems in gaining informed consent from psychiatric patients" (1982) 31 Emory LJ 345 at 358. Dull adds the following observation on the effect of delusional ideation on capacity: "All commentators agree that delusions only leave capacity intact if the delusions are limited to other topics entirely unrelated to the treatment decision. However, delusional thinking may preclude a patient's appreciation of the information with respect to himself, or may cloud his more basic 'understanding' that the symptoms are impairments, not enhancements." (at 61-62).

125 Dull, ibid at 60-62, 68-70.

126 Ibid at 66.

127 See, e.g., Sevels v. Fleming, 2007 CanLII 18577 (ON SC); Gajewski v. Wilkie, 2014 ONCA 897 (CanLii); D'Almeida v. Barron, 2010 ONCA 564 (CanLII) (at para 25: the appellant "believes that he will continue to improve without the medication. The respondent's opinion that the appellant's condition will deteriorate is firmly anchored in the evidence, including evidence of the experience both before and after the appellant began treatment").
} 
deliberation on how far respect for alternative or dissident evaluation of one's condition may reach, or what is required (in the absence of acceptance of treatment) to demonstrate appreciation. However, there have been some limited exceptions, foregrounding the principle that the determination of incapacity must not be based on the individual's failure to agree with a given diagnosis or with the need for a (specific) treatment, ${ }^{128}$ and the importance of considering contextual factors that may be impeding the individual's ability to demonstrate legal capacity. ${ }^{129}$

\section{Critiques}

One critique of the legal apparatus constructed around the capacity to make treatment choices is that it is of little consequence in practice; that is, given that evaluation of treatment capacity is most commonly resorted to in the face of treatment resistance, in addition to the discretion built into the legal standard, such evaluations may amount in practice to a pro forma exercise in rationalizing involuntary treatment rather than a principled dividing line between whose wishes should and should not be respected. ${ }^{130}$

Apart from this fundamental concern, there are two major streams of critique that run at odds with each other. On the one side are those who argue that the dominant legal standards fail to pick up on forms of impaired decision-making that should, but do not, register as bases for concluding legal incapacity. For instance, some argue that existing standards are inordinately cognitive in orientation, and so neglect pathological disturbances of affective or evaluative aspects of decision-making. ${ }^{131}$

On the other side are those who argue that standards of legal capacity unjustly discriminate against persons with mental health and intellectual disabilities. One version of this critique argues that there is never justification for denying legal agency to a person on the basis of differences in mental functioning; instead, the will and/or preferences of

\footnotetext{
${ }^{128}$ See Neto v. Klukach, [2004] OJ No 394, [2004] CCS No 8158 (Sup Ct) (although, as Dull points out, this was a decision in which the individual originally assessed as incapable accepted the diagnosis of bipolar disorder and additionally acknowledged a need for treatment -- she preferred lithium to antipsychotic medications); see also Anten v. Bhalerao 2013 ONCA 499 (CanLII).

${ }_{129}$ Crewe (Re), 2007 NSSC 322 (CanLII), 259 NSR (2d) 273.

${ }^{130}$ See, e.g., A. Kaiser, "Mental Disability Law" supra note $x$ at 300: "[T]he twin elements of the malleability of these structuring devices [i.e., statutory criteria for assessment of capacity] and the comparative invisibility of most determinations may turn statutory statements into merely symbolic gestures."

${ }^{131}$ For instance, some clinicians and bioethicists have observed that persons diagnosed with anorexia nervosa tend to exhibit ambivalence as between an overriding will to thinness and a stated preference to avoid death or serious heath consequences. Moreover, they argue that such ambivalence (which they suggest is rooted in affective and volitional rather than strictly cognitive dimensions of decision-making) represents a form of impaired decision-making that "may be missed by standard assessment criteria". (Tony Hope et al, "Agency, ambivalence and authenticity: the many ways in which anorexia nervosa can affect autonomy" (2013) 9(1) International Journal of Law in Context 20 at 21). See also Louis Charland et al, “Anorexia Nervosa as a Passion" (2013) 20(4) Philosophy, Psychiatry \& Psychology 353. See also Catriona MacKenzie and Wendy Rogers, "Autonomy, vulnerability and capacity: a philosophical appraisal of the Mental Capacity Act" (2013) 9(1) International Journal of Law in Context 37 (assessors should "refer to a range of more demanding autonomy conditions relating to authenticity, diachronic coherence and consistency, accountability to others, and affective attitudes towards oneself.")
} 
all persons should have normative force, subject to legal limits otherwise regulating social interaction. ${ }^{132}$ To this may be added the critique that the standards for legal capacity do not reflect the often intuitive or unreflective, frankly irrational ways that people tend to make decisions in everyday life, ${ }^{133}$ here the argument is that the law should not place higher expectations on those targeted for capacity assessment than on others who are accorded reflexive respect for their decisions. Finally, the discrimination critique draws on the broad discretion built into standards of incapacity, along with the deference typically accorded assessors by oversight bodies, to argue that capacity assessment masks the arbitrary or systematic imposition of professional values and preferences over those of persons assessed.

Treatment Decision-Making in the Event of Incapacity

In British Columbia, mental health legislation provides for treatment of involuntary psychiatric patients at the discretion of the treating psychiatrist, regardless of treatment capacity status; in Saskatchewan and Newfoundland, too, involuntary patients (who are in these jurisdictions by definition deemed incapable of treatment decision-making) are subject to treatment at the physician's discretion. ${ }^{134}$ Otherwise, apart from the possibility of an advance directive (in jurisdictions where these have direct effect, absent a designated proxy), ${ }^{135}$ treatment decisions in the event of legal incapacity are made by a substitute decision-maker - typically identified by way of a ranked list of familial relationships, with the Public Guardian as last resort. ${ }^{136}$

There are three main ways that statutory regimes structure the decisions of substitute decision-makers. These are: 1) prioritization of prior capable wishes (with reversion to a best interests standard where such wishes are unknown or inapplicable to the circumstances) ${ }^{137}$; 2) a best interests standard, which may or may not include consideration of prior capable (and/or contemporaneous) wishes, along with other matters, such as risk-benefit and least restrictive means assessment; ${ }^{138}$ and 3 ) a hybrid

\footnotetext{
${ }^{132}$ See e.g. Michael Bach \& Lana Kerzner, supra note 94 at 103-114 (support for the exercise of legal capacity as an expression of the duty to accommodate disability under statutory human rights laws and s.15 of the Charter); Eilionoir Flynn \& Anna Arstein-Kerslake, "The Support Model of Legal Capacity: Fact, Fiction or Fantasy?” (2014) 32 Berkeley Journal of International Law 134 esp at 127-130; Tina Minkowitz, "The United Nations Convention on the Rights of Persons with Disabilities and the Right to be Free of Nonconsensual Psychiatric Interventions" (2007) 34(2) Syracuse Journal of International Law and Commerce 405 at 408-412. See also the Committee on the Rights of Persons with Disabilities, General Comment No. 1 (2014): Article 12 (CRPD / G / GC / 1) (discussed below).

${ }^{133}$ On this general claim, see e.g. Dan Ariely, Predictably Irrational: The Hidden Forces that Shape our Decisions (New York: Harpercollins, 2008).

${ }^{134}$ BC MHA, supra note x, ss 8 \& 31(1); Sask MHSA, supra note x, ss. 25(2) \& 27; Newfoundland MHCTA, supra note $\mathrm{x}, \mathrm{s.35}$.

${ }^{135}$ For in-depth discussion of differences among Canadian jurisdictions with regard to the legal effect given advance directives, see Advocacy Centre for the Elderly and Dykeman Dewhirst O'Brien LLP, Health Care Consent and Advance Care Planning in Ontario (Toronto: Law Commission of Ontario, 2014) (Part V: "Health Care Consent and Advance Care Planning: A National and International Review").

136 See, e.g., NS IPTA, s.38; NS Hospitals Act, s.54; NS Personal Directives Act, s.2(j), s.14.

${ }^{137}$ See Ontario HCCA, s.21; NWT MHA, Nunavut MHA, s. 19.4 (7); BC HCCFAA, s.19 (per s.2, the HCCFAA does not apply to treatment of involuntary patients under the BC MHA).

138 See, e.g., Alta MHA, s.28(4).
} 
model requiring compliance with prior capable wishes unless this would endanger the physical or mental health of the individual or a third party. ${ }^{139}$

Ontario's Health Care Consent Act requires that substitute decision-makers comply with the individual's prior capable wishes (whether or not the person is an involuntary patient). ${ }^{140}$ However, there are some caveats. First, the requirement is limited to prior capable wishes that are "applicable to the circumstances." 141 In Conway v. Jacques,${ }^{142}$ the Ontario Court of Appeal relied on this requirement to uphold a tribunal decision invalidating a decision of Conway's mother to refuse anti-psychotic medications on his behalf. In particular, the Court confirmed that deterioration of Conway's condition, along with "radical" improvements in anti-psychotic medications, had rendered his prior capable wish not to be treated with such medications inapplicable. ${ }^{143}$

Second, the Health Care Consent Act allows departure from a prior capable wish where it is "impossible" for the substitute decision-maker to comply with the wish. ${ }^{144}$ Finally, the substitute decision-maker (or physician "on the substitute's behalf") may apply for permission to depart from a prior capable wish on the basis that the person, if she were capable, would probably give consent because the likely result of the treatment is significantly better than would have been anticipated in comparable circumstances at the time the wish was expressed. ${ }^{145}$

\section{New Directions in Law and Policy: Supported decision-making}

Canadian law has crafted a web of protections around medical treatment -- protections rooted in the expectation that treatment requires consent, and that consent must be voluntary, informed, and capable. In the case of psychiatric treatment, however, these protections are hedged with qualifications. In the psychiatric hospital context, in

\footnotetext{
${ }^{139}$ NS IPTA, s.39(b).

${ }^{140}$ See HCCA, s.21. This element of Ontario's law reflects the Ontario Court of Appeal's ruling in Fleming v. Reid (1991), 4 O.R. (3d) 74 (C.A.), wherein the Court determined that Ontario's Mental Health Act was in breach of s.7 of the Charter, in permitting a tribunal to disregard the prior capable wishes of involuntary psychiatric patients deemed incapable of treatment decisions. On the conflicting interpretations of the breadth of the court's holding, (i.e., whether the unconstitutionality consisted in overriding prior capable wishes per se, or simply in overriding those wishes without a hearing), see Peter Carver, "Mental Health Law in Canada" in Canadian Health Law and Policy, Jocelyn Downie, Timothy Caulfield \& Colleen Flood, eds (Markham: LexisNexis, 2011) 341 at 358.

${ }^{141}$ HCCA, s.21(1).

142 (2002), 59 O.R. (3d) 737.

${ }^{143}$ Ibid at paras 37-38. Given the recent deflation of claims about the radically improved efficacy and side effect profiles of the new ("atypical") generation of antipsychotic medications, the assertions made by the Board (and repeated with approval by the court) in Conway $v$ Jacques urge caution where improvements in efficacy are advanced as a basis for departing from prior capable wishes. (See, e.g., L. Hartling et al, "Antipsychotics in adults with schizophrenia: comparative effectiveness of first-generation versus secondgeneration medications: a systematic review and meta-analysis" (2012) 157(7) Ann Intern Med. 498). At one point Sharpe JA for Court of Appeal remarks: "The improvement is so significant that the Board analogized the new anti-psychotic medication to the advent of penicillin for the treatment of infections." (at 38)

${ }^{144}$ HCCA, s.21(1) 2.

${ }^{145}$ HCCA, s.36.
} 
particular, the putatively universal legal requirement of consent may be suspended or significantly circumscribed, such that even for voluntary patients, treatment choice may be said to take place in the shadow of coercion.

Fights about psychiatric treatment tend to involve starkly opposed perspectives as between medical professionals (perhaps also family members) and those identified for treatment, on the facts as well as values of relevance to the decision. Such fights are not likely to yield clear winners. That is, just as there is no cause for celebration in forced treatment (even if one favours a "human needs" approach), ${ }^{146}$ so there is typically no great personal victory in being granted the right to refuse - at least, not if that is all one has.

The title of this chapter points to something beyond the standoff of power and resistance described so far. It contrasts "insight" (a term often used as a proxy for legal capacity, describing acceptance of illness and of the need for treatment) with "incite" (meaning "to provoke action," as in: to incite a riot). The idea is to suggest that the law on consent to psychiatric treatment may be undergoing a shift in orientation from a primary preoccupation with expert evaluation of the internal capacities of the psychiatric subject to a concern that public authorities provide meaningful relational supports for treatment choice - as one component of a broader duty to provide the social determinants of mental health.

\section{What is supported decision-making?}

Earlier, I noted the argument that the standards of legal capacity tend to be constructed and applied in ways that discriminate against or disproportionately burden persons diagnosed with mental health disabilities. Supported decision-making has been identified as a key component of a fundamental equality- and autonomy-based "paradigm shift" aimed at displacing paternalism and disregard for the equal legal personhood of persons with disabilities, in and beyond psychiatric treatment contexts. ${ }^{147}$

Gooding writes: "Supported decision-making refers to a decision made by a person, on his or her own behalf, with support from others in order to exercise legal capacity."148 This leaves open the question of the precise nature of the state's role in creating the legal

\footnotetext{
${ }^{146}$ One of Scott Starson's doctors, in his testimony before the Ontario Consent and Capacity Board in the matter that would become Starson v Swayze, indicated that Starson's uncompromising refusal of treatment placed medical staff in a kind of "catch-22". That is, given Starson's resistance, treatment had to be administered by way of (debilitating) injectable doses of the "dirty" (the doctor's words) drug Haldol - a plan that was certain to reinforce Starson's resistance to treatment. See Sheila Wildeman, "Insight Revisited: Relationality and Psychiatric Treatment Decision-Making Capacity," in J. Downie and J. Llewellyn, eds., Being Relational: Reflections on Relational Theory and Health Law (Vancouver: UBC Press, 2011) 255 at 261 and ftn 39.

${ }^{147}$ See the sources cited at note $\mathrm{x}$, supra.

${ }^{148}$ Piers Gooding, "Navigating the 'Flashing Amber Lights' of the Right to Legal Capacity in the United Nations Convention on the Rights of Persons with Disabilities: Responding to Major Concerns" (2015) 15(1) Human Rights Law Review 45 (at p9 SSRN). See also Piers Gooding, "Supported Decision-Making: A Rights-Based Disability Concept and Its Implications for Mental Health Law" (2012) 20 Psychiatry, Psychology and Law 431.
} 
and social conditions for supported decision-making and more broadly for supporting legal capacity. In fact, there is no consensus on this question, nationally or internationally; however, there have in recent years been a number of high profile deliberative processes aimed at generating ideas and garnering consensus on the theory and practice of supported decision-making. ${ }^{149}$

Much of the contemporary interest in supported decision-making may be traced to the advocacy work of Disabled Persons Organizations (DPOs) during negotiations of the U.N. Convention on the Rights of Persons with Disabilities ${ }^{150}$ (CRPD) (discussed in Chapter 3). DPOs like the World Network of Users and Survivors of Psychiatry (WNUSP) and Inclusion International argued for a fundamental change in the conceptualization of legal capacity from an internal deficit of the individual to a product of social, institutional, and legal arrangements. ${ }^{151}$ For instance, drawing social and economic rights together with traditional norms of informed consent, WNUSP stated (in comments informing the draft text presented for negotiation): "[A]utonomy and selfdetermination are dependent on having sufficient access to resources so that economic and social coercion do not lead to decision-making that does not reflect the person's own values and feelings," and are "also dependent on the existence of meaningful alternatives related to the particular decision at issue." 152

The statement affirms the understanding that all persons require structural supports (economic, institutional, emotional) in order to develop and express autonomy. It is this understanding that lays the foundation for the interrelated concepts of legal capacity and supported decision-making expressed in the CRPD's Article 12, which declares that

\footnotetext{
${ }^{149}$ See, e.g., Standing Committee on Social Issues, Substitute Decision-Making for People Lacking Capacity (Sydney: Parliament of New South Wales, Legislative Council, 2010); Victorian Law Reform Commission [VLRC], Guardianship: Final Report. (Melbourne: VLRC, 2012); Australian Law Reform Commission [ALRC], Equality, Capacity and Disability in Commonwealth Laws: Final Report (Sydney: ALRC, 2014); Law Commission of Ontario [LCO], Legal Capacity, Decision-Making and Guardianship. Discussion Paper May 2014 (Toronto: LCO, 2014); Council of Europe, Commissioner for Human Rights (2012) Who gets to decide? Right to legal capacity for persons with intellectual and psychosocial disabilities; Irish Human Rights Commission IHRC Observations on the Assisted Decision-Making (Capacity) Bill 2013, March 2014 (Dublin, 2014); Houses of the Oireachtas Committee on Justice Defence and Equality, "Report on hearings in relation to the scheme of the Mental Capacity Bill, May 2012" 31/JDAE/005.

15024 January 2007, A/RES/61/106, available at: http://www.refworld.org/docid/45f973632.html [accessed 12 October 2015]

${ }^{151}$ For an account of the advocacy efforts of DPOs at the negotiations in respect to Article 12, see Amita Dhanda, "Legal Capacity in the Disability Rights Convention: Stranglehold of the Past or Lodestar for the Future?" (2007) 34 Syracuse J. Int'l L. and Com. 429; Rosemary Kayess and Phillip French, “Out of Darkness into Light? Introducing the Convention on the Rights of Persons with Disabilities" (2008) 8(1) Human Rights Law Review 1.

${ }^{152}$ The passage continues: "This is a statement of the interdependence and inter-relatedness of rights, and also a reiteration of article 22 of the Universal Declaration of Human Rights, which recognizes that economic, social and cultural rights are necessary to the free and full development of the personality". UN Ad Hoc Committee on an International Convention: Working Group, "Contribution by World Network of Users and Survivors of Psychiatry (WNUSP)" at http://www.un.org/esa/socdev/enable/rights/wgcontribwnusp.htm. On the establishment of the Working Group, see http://www.un.org/esa/socdev/enable/rights/ahcwg.htm
} 
persons with disabilities enjoy legal capacity on an equal basis with others in all aspects of life, and that States Parties must take appropriate measures to ensure persons with disabilities have access to the support they may require to exercise their legal capacity. ${ }^{153}$

The question is, what does Article 12 - and, moreover, a legitimate autonomy- and equality-respecting legal regime - entail? As discussed in Chapter 3, Canada has registered an interpretive declaration / reservation with regard to Article 12, whereby it asserts the legitimacy of regimes of substitute decision-making. ${ }^{154}$ However, the normative force of Article 12 is nonetheless registered in the increasing attention paid to supported decision-making in law reform processes in and beyond Canada. ${ }^{155}$ Moreover, in its General Comment on Article 12, ${ }^{156}$ the CRPD Committee states unequivocally the following two interpretive positions that starkly conflict with Canada's. First, all persons enjoy equal legal capacity, both in the sense of having equal status as persons and in the sense of having the power to exercise the rights one holds as a legal person. ${ }^{157}$ Second, states must abolish substitute-decision-making regimes premised on i) vitiation of legal capacity by way of status-based, outcome-based, or functional assessments; ii) appointment of a substitute decision-maker by "someone other than the person concerned," and against his or her will; and iii) "best interests" decision-making permitting non-conformity with the individual's "own will and preferences." 158 In place of such regimes, states must provide persons with "access to support in the exercise of their legal capacity" so as to "to enable them to make decisions that have legal effect."159

The radicality of these statements rests in part on their motivating thesis about what it is about the human personality that compels respect for decisions -- not rational-cognitive (or cognitive-affective) functioning, but "will and preference."160 In addition, the General Comment reflects the thesis that dominant models of legal capacity are irredeemably steeped in relationships of power and subordination. In response, recent debates have been increasingly directed at concerns about whether or how legitimate limits may be set to respect for will and preference, if not by reference to a functional standard of capacity.

\section{Operationalizing supported decision-making}

The roots of the idea of supported decision-making reach back to a period before work on the CRPD commenced in earnest, to decades of disability rights advocacy on the part of

\footnotetext{
${ }^{153}$ UN CRPD, supra note $\mathrm{x}$, Article 12(2)\&(3). Subsection 12(4) addresses safeguards relating to the exercise of legal capacity, and ss.12(5) addresses financial and property interests.

${ }^{154}$ United Nations, Convention and Optional Protocol Signatures and Ratifications, online: UN Enable http://www.un.org and see Nicholas Caivano, "Conceptualizing Capacity: Interpreting Canada's Qualified Ratification of Article 12 of the of the UN Disability Rights Convention" (2014) 4:1 Western Journal of Legal Studies (online).

${ }^{155}$ See note $\mathrm{x}$, supra [Australian, Canadian, Irish, European law commission documents].

${ }^{156}$ CRPD Committee, General Comment No. 1 (2014): Article 12 (CRPD / G / GC / 1).

${ }^{157}$ Ibid at paras 11-12.

${ }^{158}$ Ibid at para 23.

${ }^{159}$ Ibid at para 14.

${ }^{160}$ See Bach \& Kerzner, supra note 94 at 59-72.
} 
persons with intellectual disabilities and their families. The anti-institutionalization and community living movement - as represented, in particular, by People First Canada and the Canadian Association for Community Living - has been at the vanguard of much of this historical advocacy work, ${ }^{161}$ aimed at bringing about a shift from traditional plenary guardianship regimes to legal regimes grounding formal opportunities to obtain support for the development and expression of independence.

The fruits of this advocacy may be seen, for instance, in BC's Representation Agreement $A c t,{ }^{162}$ which (while explicitly ruling out a representative's refusal of admission or treatment under the Mental Health Act), ${ }^{163}$ allows appointment of a representative either to assist one with decisions, or to make decisions on one's behalf, or both. Apart from formal legal recognition given those providing decision-making assistance, the Act adopts a standard of capacity to appoint a representative that departs from the typical cognitive-based test -- instead stating a range of relevant factors, including whether the adult has shown a desire to appoint the representative, "whether the adult has a relationship with the representative that is characterized by trust," 164 and (gesturing to the continued possibility of substitute decision-making under this Act) whether the adult is able to understand that by appointing a representative that person may make decisions "on behalf of" the adult. ${ }^{165}$ Another key feature is the standard to which the representative must adhere. That is, even where the representative is to "make' decisions for the adult, he or she is to decide in accordance with the adult's current wishes, rather than applying a best interests standard or prioritizing prior capable wishes ${ }^{166}$-- unless the latter are conveyed through a formal instrument intended to override future preferences. ${ }^{167}$ In a final gesture toward best interests, however, the Act provides the caveat that current wishes are to be complied with only "if it is reasonable to do so."168

\section{Implications for mental health law and policy}

Supported decision-making has not as yet been introduced into any Canadian laws on involuntary psychiatric treatment or hospitalization. Correspondingly, there are deep debates about the theoretical premises and practical limits of supported decision-making, understood as a radial alternative to legal incapacity and substitute decision-making in the

\footnotetext{
${ }^{161}$ Ibid. at 33-34: "[T] he national self-advocacy association of people with intellectual disabilities in Canada, People First of Canada, and the national family-based advocacy association, the Canadian Association for Community Living (CACL), have been actively advocating over the past 20 years for reform of Canada's legal capacity and decision-making regimes, demanding laws which are more consistent with the manner in which many members of the community make and communicate their decisions. At the founding conference of People First Canada, in 1991, the first resolution adopted by the membership was a call to end guardianship because of its violation of the right to make one's own decisions. The CACL launched a Task Force on Alternatives to Guardianship at around the same time to propose directions for law reform consistent with the call by People First of Canada."

162 Representation Agreement Act, RSBC 1996, c 405.

163 Ibid, s. 11.

164 Ibid, s.8(2).

165 Ibid.

166 Ibid, s.16(2).

${ }^{167}$ Ibid, s.16(2.1) (permitting Ulysses agreements).

168 Ibid, s.16(2)(b).
} 
mental health law context. ${ }^{169}$ Yet efforts are nonetheless being made to explore the scope and limits of government and/or civil society responsibilities for supporting legal capacity. ${ }^{170}$

Critiques raised around the concept of supported decision-making in recent years include the observation that there is as yet no solid evidentiary base from which to gauge effectiveness in enabling autonomy or resource implications. ${ }^{171}$ A more pointed critique is that supported decision-making laws (at least, where framed as a replacement for substitute decision-making) may impede accountability for abuse or exploitation, given that the formal source of decisions remains the individual him or herself. ${ }^{172}$ Perhaps most worryingly for advocates, the argument is made that supportive decision-making regimes may have a "net-widening" effect, so expanding formal (as well as informal) expectations that control or authority over fundamental personal decisions be shared with family members or others. ${ }^{173}$

Still others argue that the practices and concepts of supported decision-making are rooted in the personal circumstances and social movement politics of persons with intellectual disabilities, and are as such not necessarily transferable to persons with mental health disabilities. ${ }^{174}$ For instance, Del Villar argues that persons with mental health disabilities

\footnotetext{
${ }^{169}$ See, e.g., Piers Gooding ("Navigating the "Flashing Amber Lights"”) supra note x; Katrine Del Villar, "Should Supported Decision-Making Replace Substituted Decision-Making? The Convention on the Rights of Persons with Disabilities and Coercive Treatment under Queensland's Mental Health Act 2000" (2015) 4 Laws 173. Increasing attention is being paid, as well, to the implications of Article 12 for laws on criminal responsibility: see Jill Peay, "Mental incapacity and criminal liability: Redrawing the fault lines?" (2015) 40 Int'l J of Law and Psychiatry 25.

${ }^{170}$ For discussion of regimes of supported / assisted and co-decision-making in Canada, beyond BC's Representation Agreement Act, see the Law Commission of Ontario, at 122-141.

${ }^{171}$ See, e.g., Nina A. Kohn, Jeremy A. Blumenthal and Amy T. Campbell, "Supported Decision-Making: A Viable Alternative to Guardianship?” (2013) 117(4) Penn State Law Review 1111 at 1128; Terry Carney \& Fleur Beaupert, "Public and Private Bricolage - Challenges Balancing Law, Services and Civil Society in Advancing CRPD Supported Decision-Making”36(1) University of New South Wales Law Journal 175. 172 See Kohn et al, ibid at 1123; Piers Gooding, supra note y ("Flashing Amber Lights") at 15-18. And see Law Commission of Ontario, Legal Capacity, Decision-Making and Guardianship: Discussion Paper (Toronto: May 2014): “As supporters are intended to have less of a role in the decisions, they are accorded less responsibility for the outcomes of decision-making, and the lack of an objective standard makes it more challenging to hold them to account where their influence on the supported person has led to an inappropriate outcome." (at 134)

173 Ontario Law Commission, ibid at 136 (noting a "concern about "slippage" under supported decisionmaking systems, whereby persons designated to provide support may in fact act as substitutes".) See also Terry Carney ("Public and Private Bricolage") supra note x at 193-196; and Tina Minkowitz, "Legal Capacity from a Psychosocial Disability Perspective: A Discussion Paper" (2014) available at SSRN: http://ssrn.com/abstract=2374733 at para 9: "Although we participated in the creation of the support model and its distinction from substitute decision-making, many users and survivors of psychiatry and people with psychosocial disabilities are uncomfortable with creation of legal mechanisms for support. We know that legal mechanisms can and will be used to take control of a person's destiny contrary to his/her own will and desires."

174 Ontario Law Commission, ibid at 135-36: "The concept of supported decision-making has its roots mainly in the intellectual disability community, and it is this community which has tended to embrace it Many of those working in the area see supported decision-making as a more challenging fit for persons with mental health disabilities or older persons with age-related disabilities such as dementia: certainly,
} 
may lack the familial and social support networks assumed by models of supported decision-making. ${ }^{175}$ Related arguments focus on hard cases- for instance, cases wherein will and preference may be said to conflict (as some suggest of some persons with anorexia, for whom the overriding will to be thin may conflict with the preference to live). ${ }^{176}$ Del Villar makes the overarching point (in terms that recall the difficulty Canadian equality rights claimants have had under s.15 of the Charter) that "'discrimination' does not mean any form of differential treatment, but only 'unjustified differential treatment" "177 Thus we return to the question of whether authorizing involuntary or non-voluntary (i.e., incapacity-based) treatment of persons deemed mentally disabled is justified, and so proportionate, taking account of liberty and equality rights and any competing public or individual interests.

In light of these critiques, what are the prospects for integrating the principles and norms of supported decision-making into mental health law and policy?

Advocacy for a reconstructed approach to legal capacity among users and survivors of psychiatry has centred upon advocacy and peer support, ${ }^{178}$ including formal and informal mechanisms aimed at preventing and de-escalating crisis, and assistance in navigating and accessing social services. The contemplated measures of support include accommodations at the sites of decision-making as well as broader social and economic supports. Thus relevant institutional reforms may include systemic reforms -- for instance, redirecting persons experiencing mental health crisis from emergency wards to environments more equipped for crisis de-escalation and one-to-one engagement. ${ }^{179}$ Some draw on the Swedish precedent of the PO [Personal Ombuds] Skane, ${ }^{180}$ which involves independent advocates whose role it is to enter into non-coercive, facilitative

where forms of supported decision-making have been implemented in Canada, there appears to have been less interest or uptake within these groups."

${ }^{175}$ Katrine Del Villar, "Should Supported Decision-Making Replace Substituted Decision-Making? The Convention on the Rights of Persons with Disabilities and Coercive Treatment under Queensland's Mental Health Act 2000" (2015) 4 Laws 173 at 191-192.

${ }^{176}$ See Hope et al, supra note x; Charland, supra note x; Christopher James Ryan \& Sascha Callaghan, "Treatment Refusal in Anorexia Nervosa: The Hardest of Cases" (2014) 11 Bioethical Inquiry 43. And see Gooding, supra note x ("Flashing Amber Lights") at [22-25 SSRN], addressing anorexia nervosa (i.e., conflicting will and preference) as well as cases involving lack of awareness of foreseeable harmful consequences (i.e., back to the domain of failed insight), and raising the question of how law might provide a response without resting on disability-based distinctions. In that vein, see Piers Gooding and Eilionóir Flynn, "Querying the Call to Introduce Mental Capacity Testing to Mental Health Law: Does the Doctrine of Necessity Provide an Alternative?" (2015) 4 Laws 245.

177 Del Villar, supra note $\mathrm{x}$ at 183.

${ }^{178}$ See, e.g., Tina Minkowitz, "The United Nations Convention on the Rights of Persons with Disabilities and the Right to be Free of Nonconsensual Psychiatric Interventions" (2007) 34(2) Syracuse Journal of International Law and Commerce 405 at 409, and "Legal Capacity from a Psychosocial Disability Perspective: A Discussion Paper" (2014) available at SSRN: http://ssrn.com/abstract=2374733; Soumitra Pathare \& Laura S. Shields, "Supported Decision-Making for Persons with Mental Illness: A Review" (2012) 34(2) Public Health Reviews 1.

${ }^{179}$ See Susan Stefan, Emergency Department Treatment of the Psychiatric Patient: Policy Issues and Legal Requirements (Oxford: Oxford University Press, 2006).

${ }^{180}$ See (online) "Swedish user-run service with Personal Ombud (PO) for psychiatric patients" (http://www.po-skane.org/ombudsman-for-psychiatric-patients-30.php) [date accessed Oct 12, 2015]. And see the discussion of the PO Skane in the LCO Discussion Paper, supra note $\mathrm{x}$ at 130-131. 
relationships with persons with mental health disabilities who otherwise lack social or familial supports, to assist in identifying and realizing the individual's goals. ${ }^{181}$ Arguably, a blend of civil society mechanisms (like the Hearing Voices Network ${ }^{182}$ ) and state mechanisms are required if the paradigm shift envisioned by advocates is to be achievable. ${ }^{183}$

The debates, in and beyond Canada, about what it would mean to support rather than reflexively curtail the autonomy interests of persons with mental health disabilities where their or others' interests appear to be at risk, reflect a deep shift in human rights advocacy as relates to psychiatric treatment. That shift is from an exclusive liberal or libertarian emphasis on the right to refuse (although this remains a central pillar of any selfrespecting claim to human rights advocacy in this area) to a new emphasis on state duties to provide the conditions for equal participation in the full range of basic social goods and opportunities -- not only equal basic liberties (including the right to make treatment decisions), but equal access to housing, nutrition, education, work, political life, etc. That is to say that supported decision-making in relation to psychiatric treatment - which arguably entails a right to a meaningful range of therapeutic options as well as supports for the exercise of choice among those options - is one piece of a broader picture of what it means to promote full social inclusion of persons with disabilities. This marks an important development in the discursive environment informing mental health law and policy.

\section{Conclusion}

The concept of supported decision-making animating contemporary debates about mental health law and policy brings the traditional understanding of consent to treatment, rooted in an informational transaction between health professional and patient, into contact with a broader, contextualized model of decision-making, sensitive to how autonomy is advanced or impeded in mental health care contexts. The effect is to call attention to the ways that all treatment choices are embedded in power relationships across health and related social systems. Yet this first step of reconceptualizing treatment choice as a cultural and interpersonal construct, produced through material supports and mutual efforts at interpretation, ${ }^{184}$ does not in itself provide a clear way forward in terms of

\footnotetext{
${ }^{181}$ Ibid.

182 The Hearing Voices Network originated in the Netherlands in 1987, and has since taken on members in many countries. It brings together persons who hear voices and their allies with the aim of assisting those affected in integrating the experience of voices into their lives. For the UK-based network, Intervoice, see http://www.intervoiceonline.org. See also Roc Morin, "Learning to Live with the Voices in Your Head" (Nov 4, 2014) The Atlantic http://www.theatlantic.com/health/archive/2014/11/learning-to-live-with-thevoices-in-your-head/382096/.

${ }^{183}$ For an evaluation of a range of models of state-based disability supports / funding models, see Andrew Power, Janet Lord and Allison deFranco, Active Citizenship and Disability: Implementing the Personalisation of Support (Cambridge: Cambridge University Press, 2013).

${ }^{184}$ For an example of deep reconceptualization of the concept of "insight" which grounds neurobiological accounts of psychiatric treatment refusal, see Tranulus, Corin and Kirmayer, "Insight and Psychosis: Comparing the Perspectives of Patient, Entourage and Clinician" (2008) 54:3 Int'l J of Law \& Psychiatry 225 (defining insight as "an active, interactional and negotiated process of making meaning of symptoms and illness").
} 
mental health law and policy reform. As the debates continue, we are likely to see more fine-grained analyses of what constitutes discrimination and justified limits on rights both rights to supports and the right to refuse.

The political developments leading to the recent interest in supported decision-making in (and beyond) mental health law challenge the conventional framing of consent to or refusal of psychiatric treatment as a site of unbridgeable difference. These developments speak to the purpose and the potential of law, not as an instrument for delivering health or for reinforcing the professional norms of other disciplines, but rather as a forum for ongoing deliberation and contestation about the fundamental values and norms by which we govern ourselves. What is necessary for realization of this bridging function of law, however, is meaningful access - not only mechanisms for asserting one's rights at the embattled site of psychiatric treatment refusal, but also participatory parity in broader law reform processes. At the same time, meaningful access - and with this, meaningful conversation -- requires overcoming the attitudinal and other institutional biases that have historically worked to discount the choices and perspectives of those classed as mentally ill where psychiatric treatment is concerned. 